\title{
Overlap of Dopaminergic, Adrenergic, and Serotoninergic Receptors and Complementarity of Their Subtypes in Primate Prefrontal Cortex
}

\author{
P. S. Goldman-Raklc, ${ }^{1}$ M. S. Lidow, ${ }^{1}$ and D. W. Gallager ${ }^{2}$ \\ 'Section of Neuroanatomy and 'Department of Psychiatry, Yale University School of Medicine, New Haven, \\ Connecticut 06510
}

Quantitative in vitro autoradiography was used to determine and compare the areal and laminar distribution of the major dopaminergic, adrenergic, and serotonergic neurotransmitter receptors in 4 cytoarchitectonic regions of the prefrontal cortex (Walker's areas 12, 46, 9, and 25) in adult rhesus monkeys. The selective ligands, ${ }^{3} \mathrm{H}-\mathrm{SCH}-23390,{ }^{3} \mathrm{H}-$ raclopride, ${ }^{3} \mathrm{H}$-prazosin, and ${ }^{3} \mathrm{H}$-clonidine were used to label the $D_{1}$ and $D_{2}$ dopamine receptor subtypes and the $\alpha_{1} \cdot$ and $\alpha_{2}-$ adrenergic receptors, respectively, while ${ }^{125}$-iodopindolol was used to detect $\beta$-adrenergic receptors. The radioligands,

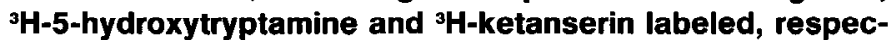
tively, the 5- $\mathrm{HT}_{1}$ and $5-\mathrm{HT}_{2}$ receptors. Densitometry was performed on all cortical layers and sublayers for each of the 7 ligands to allow quantitative as well as qualitative comparison among them in each cytoarchitectonic area.

Although each monoamine receptor was distributed in a distinctive laminar-specific pattern that was remarkably similar from area to area, there was considerable overlap among the dopaminergic, adrenergic, and serotoninergic receptors, while subtypes of the same receptor class tended to have complementary laminar profiles and different concentrations. Thus, the $D_{1}$ dopamine, the $\alpha_{1}$-and $\alpha_{2}$-adrenergic, and the $5-\mathrm{HT}_{1}$ receptors were present in highest relative concentration in superficial layers I, II, and Illa (the "S" group). In contrast, the $\beta_{1}$ - and $\beta_{2}$-adrenergic subtypes and the $5-\mathrm{HT}_{2}$ receptor had their highest concentrations in the intermediate layers, IIIb and IV (the "I" group), while the $D_{2}$ receptor was distinguished by relatively high concentrations in the deep layer $\mathbf{V}$ compared to all other layers (the "D" class). Consequently, clear laminar differences were observed in the $D_{1}$ vs $D_{2}$ dopaminergic, the $\alpha$-vs $\beta$-adrenergic, and the $5-\mathrm{HT}_{1}$ vs $5-\mathrm{HT}_{2}$ serotoninergic receptor subtypes in all 4 areas examined.

The anatomical overlap of different monoaminergic receptors in the same cortical strata suggests that there may be families of receptors linked by localization on common targets, while the complementary laminar distribution of the $D_{1}$ vs $D_{2}$, the $5-H T_{1}$ vs $5-H_{2}$ and the $\alpha$ - vs $\beta$-adrenergic receptors raises the possibility that different subtypes within a given class may have distinctive actions in cortex by virtue of their localization on different cells or possibly different

Received Nov. 6, 1989; revised Jan. 11, 1990; accepted Jan. 25, 1990.

This research was supported by grants from the USPHS.

Correspondence should be addressed to P. S. Goldman-Rakic, Section of Neuroanatomy, Yale School of Medicine, 333 Cedar Street, New Haven, CT 06510. Copyright $(\mathcal{C} 1990$ Society for Neuroscience $0270-6474 / 90 / 072125-14 \$ 03.00 / 0$ portions of the same cell. Understanding the anatomical arrangement of receptors within the cortical layers may aid in the analysis of monoaminergic modulation of higher cortical function.

The prefrontal cortex of primates is widely acknowledged to play an essential role in the regulation of behavior by goals, ideas, and expectations (for review, see Goldman-Rakic, 1987). Modern neuroanatomical tracing techniques have provided unparalleled information about the input-output relationships of this area and, together with fluorescence histochemical, autoradiographic, and immunohistochemical studies, have enabled precise localization of its major neurotransmitters and neuroactive peptides (Levitt et al., 1984; Berger et al., 1986, 1988; Lewis et al., 1986, 1987, 1988; Schwartz and Goldman-Rakic, 1988). The distribution of tyrosine hydroxylase (TH), the ratelimiting enzyme in catecholamine biosynthesis is denser in the dorsomedial and ventrolateral prefrontal areas compared with the principal sulcal cortex (Lewis et al., 1987; Berger et al., 1988). Further, the TH-positive arborizations in these areas have a bilaminar distribution with particularly high concentrations in layer I (Berger et al., 1988; Lewis et al., 1988). Noradrenergic projections to prefrontal areas also have a bilaminar distribution (Levitt et al., 1984), with highest concentrations in the infragranular layers (Morrison et al., 1982; Lewis et al., 1986; Lewis and Morrison, 1989). In contrast, serotoninergic fibers are more concentrated in layer IV and in deep layer III than in other layers (Lewis et al., 1985, 1986). The laminar profiles of some of the monoamine transmitters may be distinctive for prefrontal cortex since the distribution of TH-immunoreactive fibers (Lewis et al., 1986, 1987, 1988) and of labeling due to high-affinity uptake of ${ }^{3} \mathrm{H}$-dopamine in the prefrontal cortex (Berger et al., 1986,1988 ) differ both qualitatively and quantitatively from that in the cingulate gyrus or motor cortex (Berger et al., 1986, 1988; Lewis et al., 1986, 1987).

In contrast to the relatively broad storc of information on the monoaminergic innervation in the macaque prefrontal cortex, knowledge about the monoamine receptors which are the targets of these modulatory neurotransmitters is more limited. Detailed information on this subject would be useful in specifying more precisely the postsynaptic targets of various classes of brainstem projections to this part of the primate cortex, as well as for providing much needed information about the potential neural sites of action of psychoactive drugs, including the neuroleptic medications. Accordingly, the present study employed in vitro autoradiographic techniques (Kuhar et al., 1986; Palacios et al., 1981) and quantitative densitometry to examine the 

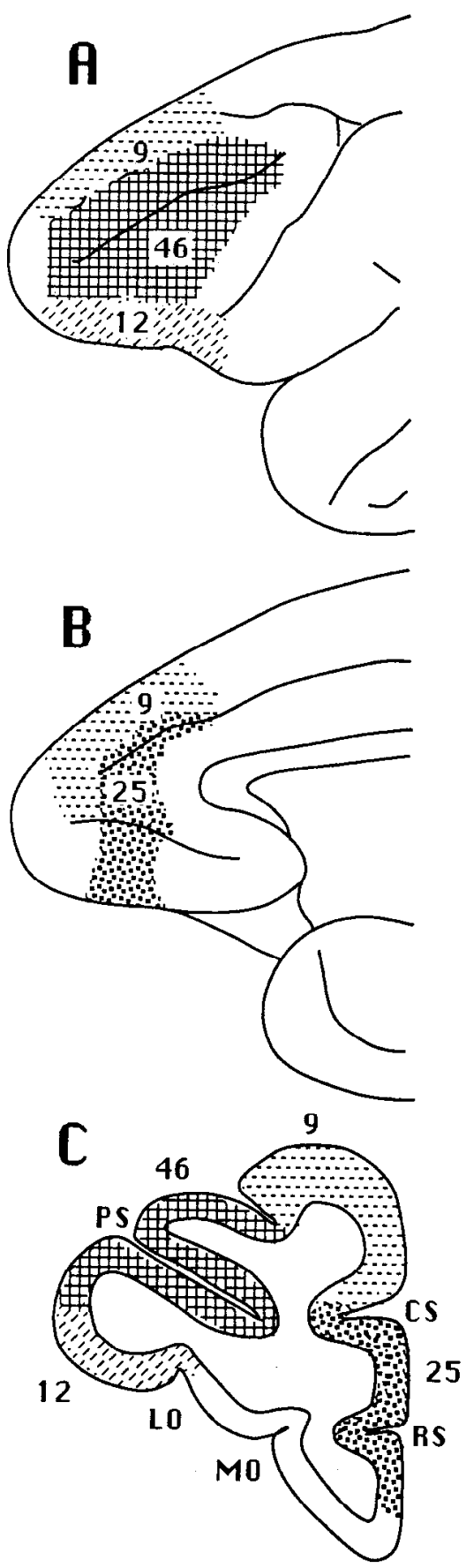

Figure 1. Schematic drawing showing the location of Walker's area 9, 46,12 , and 25 examined in the present study. PS, principal sulcus; $L O$, lateral orbital sulcus; $M O$, medial orbital sulcus; $A S$, arcuate sulcus; $C S$, cingulate sulcus; $R S$, rostral sulcus. Cytoarchitectonic areas are numbered according to Walker (1940).

distribution of 7 major monoamine receptor subtypes in 4 distinct prefrontal areas of rhesus monkeys. While $\alpha$ - and $\beta$-adrenergic-specific and $5-\mathrm{HT}_{1}$ and $5-\mathrm{HT}_{2}$ serotonin-specific ligands and their appropriate binding conditions have been known for some time (see Materials and Methods), the recent development of the dopamine-specific ligands, ${ }^{3} \mathrm{H}-\mathrm{SCH} 23390$ and ${ }^{3} \mathrm{H}$-raclopride make it possible to identify the $\mathrm{D}_{1}$ and $\mathrm{D}_{2}$ receptors without ambiguity for the first time. Finally, comparison of dopaminergic, adrenergic, and serotonergic receptors in the

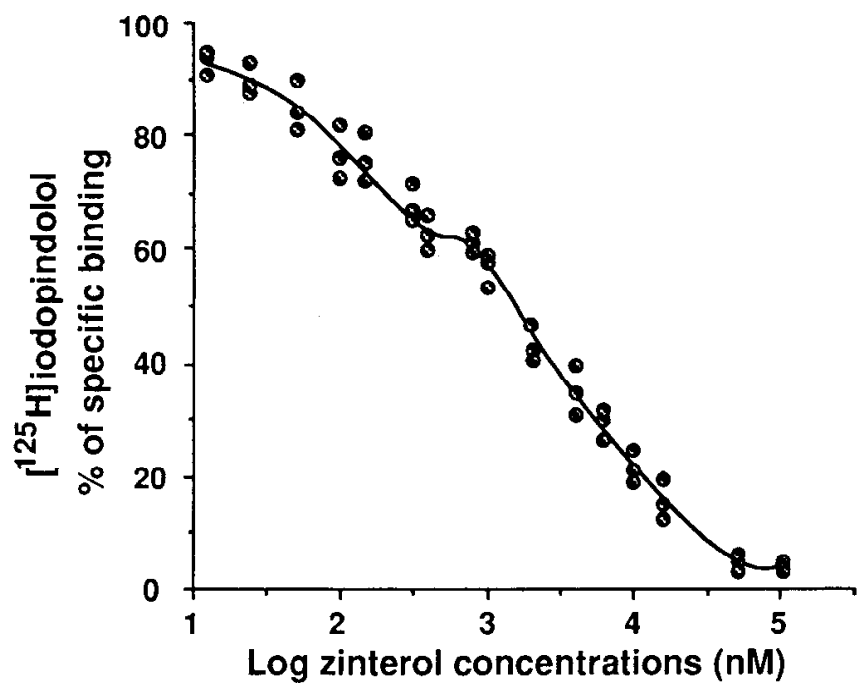

Figure 2. Inhibition of ${ }^{125} \mathrm{I}$-iodopindolol binding with the $\beta_{2}$-selective agonist, zinterol in layer II of area 9 in one of the monkeys. The line is the computer-generated best fit to a 2 -site model. In this case, $\beta_{1}$ receptors (low-affinity sites; $K_{1}=2.0 \mu \mathrm{m}$ ) constituted $66.3 \%$ and $\beta_{2}$ receptors (high-affinity sites; $K_{i}=0.04 \mu \mathrm{m}$ ) constituted $33.7 \%$ of the entire population of $\beta$-adrenergic receptors.

very same cytoarchitectonic areas of the same animals provides an opportunity for a comprehensive view of monoamine receptor allocation in prefrontal cortex.

\section{Materials and Methods}

Tissue preparation. Data on receptor binding were obtained from 4 adult ( 2 females, 2 males) rhesus monkeys (Macaca mulatta). Prefrontal cortex from each animal was sectioned at $20 \mu \mathrm{m}$ and assayed independently within 1 or 2 months of each other. The monkeys were anesthetized with Na-pentobarbital $(40 \mathrm{mg} / \mathrm{kg})$ and perfused with ice-cold PBS $(\mathrm{pH}$ $7.4,1.25$ liters) followed by 1 liter of $0.1 \%$ paraformaldehyde containing increasing concentrations of sucrose: $500 \mathrm{ml} \mathrm{0 \%}$ sucrose; $500 \mathrm{ml} 5 \%$

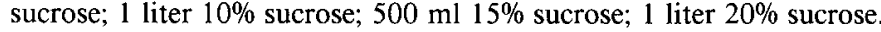
We have determined that this fixation protocol enhances tissue preservation without measurably decreasing binding or altering kinetic constants. The brains were rapidly removed, blocked, and immersed in isopentane at $-30^{\circ} \mathrm{C}$ for approximately $5 \mathrm{~min}$ before storing at $-40^{\circ} \mathrm{C}$ until use. For autoradiography, $20 \mu \mathrm{m}$ sections were processed according to individual assay procedures. In each case, tissue sections were cut not more than 2 weeks prior to assay, mounted on acid-cleaned chrom alum-coated slides, and stored at $-80^{\circ} \mathrm{C}$ until the time of assay.

Binding assays. The comparative analysis of the monoamine receptors in this study was confined to well-characterized ligands which recognize monoaminergic receptor subtypes and, if possible, label the entire subtype. As the binding procedures used have been described previously in Rakic et al. (1988) and Lidow et al. (1989a), they are summarized for each ligand only briefly here and in Table 1 . Dopamine $D_{1}$ receptors were labeled with the antagonist, ${ }^{3} \mathrm{H}-\mathrm{SCH} 23390$ (Faim et al., 1985; Boyson et al., 1986; Dawson et al., 1986, 1987), and $D_{2}$ receptors were labeled with the antagonist ${ }^{3} \mathrm{H}$-raclopride (Kohler and Radesater, 1986; Lidow et al., 1989d). The ${ }^{3} \mathrm{H}-\mathrm{SCH} 23390$ binding assay was carried out in the presence of mianserin to prevent its binding to $5-\mathrm{HT}_{2}$ (Bischoff et al., 1986) and 5-HT ${ }_{1 \mathrm{c}}$ sites (Nicklaus et al., 1988).

$\alpha_{1}$-Adrenergic receptors were labeled with the antagonist ${ }^{3} \mathrm{H}$-prazosin (Rainbow and Biegon, 1983; Rakic et al., 1988); high-affinity $\alpha_{2}$-adrenergic receptors were labeled with the partial agonist, ${ }^{3} \mathrm{H}$-clonidine (Young and Kuhar, 1980; Rakic et al., 1988), and the $\beta$-adrenergic receptors were labeled with the antagonist ${ }^{125}$ I-iodopindolol (Rainbow et al., 1984; Aoki et al., 1986; Reznikoff et al., 1986; Rakic et al., 1988). In the case of ${ }^{125}$ I-iodopindolol, the use of isoproteronol as the blanking agent assured that 5-HT, binding was not included in specific hinding (Rainbow et al., 1984). The relative percentage of $\beta_{1}$ and $\beta_{2}$ receptors was determined in experiments in which the ability of various concentrations of 

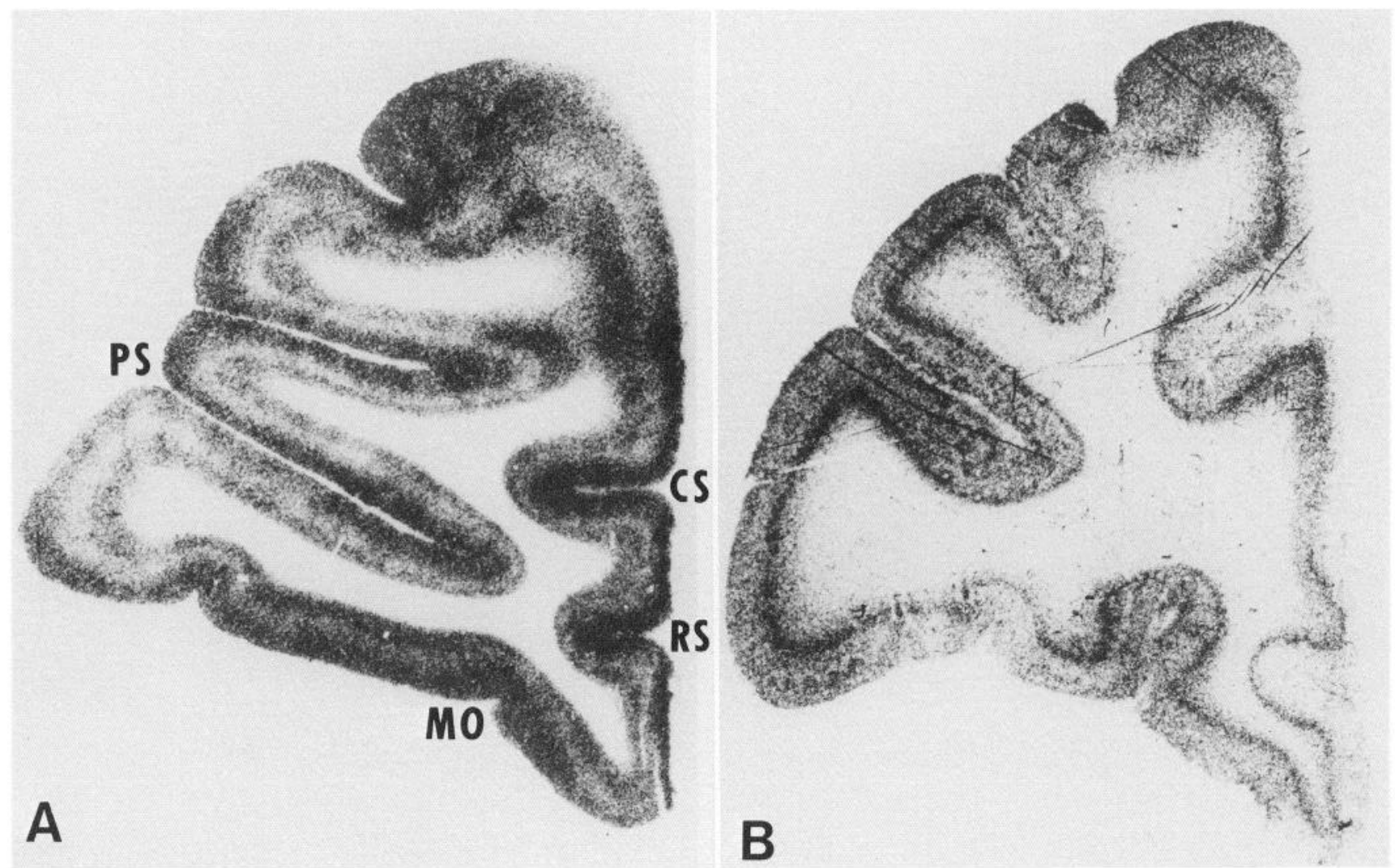

Figure 3. Autoradiographs of coronal sections cut through the prefrontal cortex. A, Labeling with ${ }^{3} \mathrm{H}-\mathrm{SCH} 23390$ in the presence of mianserin. B, Labeling with ${ }^{3} \mathrm{H}$-raclopride. Abbreviations as in Figure 1.

the $\beta_{2}$ selective agonist zinterol (Minneman et al., 1979) to inhibit the specific binding of ${ }^{125} \mathrm{I}$-iodopindolol was measured. For this purpose, tissue sections were incubated for $70 \mathrm{~min}$ with $150 \mathrm{pm}^{125} \mathrm{I}$-iodopindolol in the presence of $10 \mathrm{~nm}-100 \mathrm{~mm}$ zinterol. GTP, $100 \mathrm{~mm}$, was added to the incubation buffer (Table 1) in order to reduce agonist-specific negative cooperativity.

Serotonin 5-HT-1 receptors were labeled with the agonist ${ }^{3} \mathrm{H}-5-\mathrm{HT}$ (Pazos and Palacios, 1985; Hoyer et al., 1986; Lidow et al., 1989c), and $5-\mathrm{HT}_{2}$ receptors were labeled with the antagonist ${ }^{3} \mathrm{H}-$ ketanserin (Pazos et al., 1985; Hoyer et al., 1986; Lidow et al., 1989c). The incubation buffer for ${ }^{3} \mathrm{H}-5 \mathrm{HT}$ binding contained fluoxetine to prevent ${ }^{3} \mathrm{H}-5-\mathrm{HT}$ binding to serotonin uptake sites (Fuller, 1985) and pargyline to prevent the oxidation of the ligand by monoamine oxidase present in the tissue (Fuller, 1985). Incubation of tissue sections with ${ }^{3} \mathrm{H}$-ketanserin was conducted in the presence of prazosin to prevent its binding to $\alpha_{1}$ receptors (Leysen et al., 1982). In addition, our use of methysergide as the blank assured that the ligand did not bind to $\alpha_{1}$, histamine (Leysen et al., 1982), or a unique ketanserin site associated with dopamine nerve terminals (Leysen et al., 1987).

The binding assays of ${ }^{3} \mathrm{H}$-raclopride, ${ }^{3} \mathrm{H}$-prazosin, ${ }^{3} \mathrm{H}$-clonidine, and ${ }^{3} \mathrm{H}$-ketanserin included preincubation to eliminate endogenous ligands (see Table 1).

Quantitative densitometry. The density of receptor binding in cortical areas and layers was assessed using an image-analysis system consisting of a DAGE-MTI series 68 video camera and video signal digitizing circuitry interfaced with a Digital VT100 computer. This computerimaging system allows the overlay on a TV monitor of the digitized images of cresyl violet-stained sections and corresponding autoradiograms in order to histologically identify the autoradiographic image of each cortical layer and sublayer. The system is also capable of subtraction of the film images of sections representing nondisplaceable, hence nonspecific, binding from film images of adjacent sections with total binding, thus allowing direct on-screen observation of the images representing specific binding. Optical densities were converted to concentration of labeled compounds per tissue wet weight for each cortical layer. The optical densities for all autoradiographs produced on Ultro- film in this study were between 0.08 and 0.80 (diffuse optical density). In this range, they are linearly related to variations in tissue radioactivity (Geary et al., 1985).

The distribution of radioligands was examined in 4 subdivisions of prefrontal cortex following the cytoarchitectonic map of Walker (1940): the inferior frontal gyrus or convexity that extends from the lateral orbital sulcus to beneath the principal sulcus (Walker's area 12); the banks and depths of the principal sulcus (area 46); the dorsomedial cortex lying between the principal sulcus and longitudinal fissure (area 9); and the cortex of the medial wall anterior to the genu of the corpus callosum (area 25) (Fig. 1). Comparable regions were sampled from each animal, and the cytoarchitectonic area from which the reading was taken was confirmed by analysis of Nissl-stained sections. Sections in which the plane of section through the cortex was tangential rather than perpendicular were excluded from analysis.

Statistical analysis. Analysis of saturation binding was performed using the nonlinear curve-fitting computer programs BINKIN2 and FITFUNCTION, which were accessed through the NIH-sponsored PROPHET computer network. The analysis was based on ligand-specific binding obtained with 5 concentrations of free ligand in incubating solutions. We have previously established that 5 concentrations is the minimum number needed to obtain a relatively accurate estimate of $B_{\max }$ and $K_{d}$ for a 1 -site receptor model (Lidow et al., 1989c). Twelve replications of total binding ( 3 replicates/animal) and 4 replications of blanks (1/ animal) were measured for each concentration of free ligand. $B_{\max }$ and $K_{d}$ values obtained from different layers of each neocortical area of each animal were compared with the GT2 modification of Gabriel (1978). The latter is a conservative a posteriori multiple-comparison method based on analysis of variance that allowed us to compare each layer with each other layer within and between cortical areas. Using this method, $95 \%$ confidence intervals were calculated for each $K_{d}$ or $B_{\max }$, and these values were plotted graphically on histograms in order to provide a comprehensive visual display of all possible comparisons within and between areas. $K_{d}$ or $B_{\max }$ values with overlapping confidence intervals are statistically identical; $K_{d}$ or $B_{\max }$ values in which intervals do not overlap are considered statistically different. Plots of these com- 
Area 46

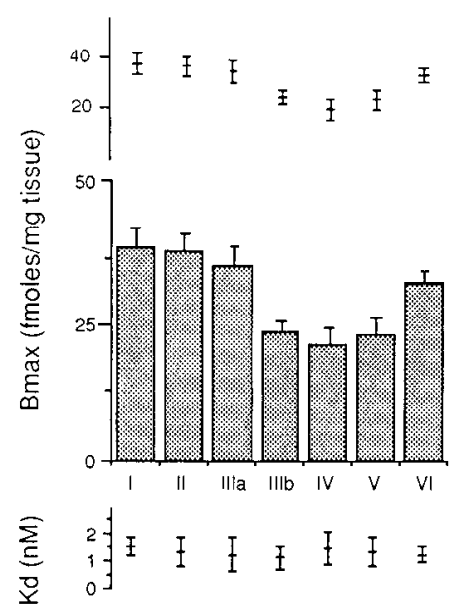

Area 12

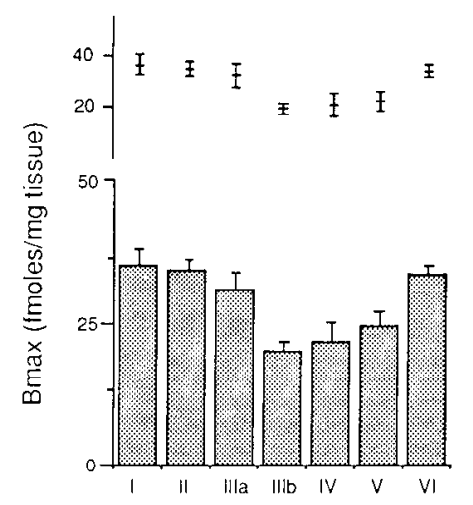

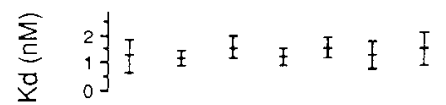

Area 9
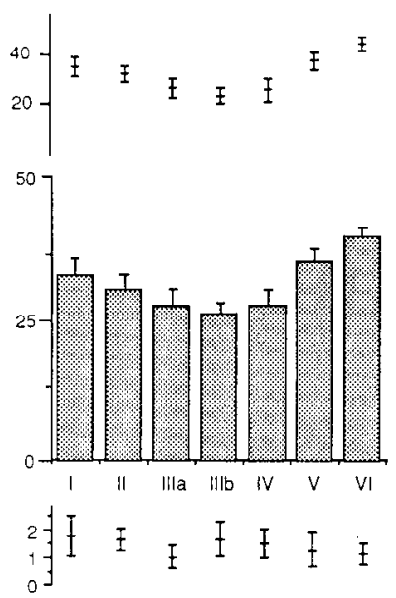

Area 25

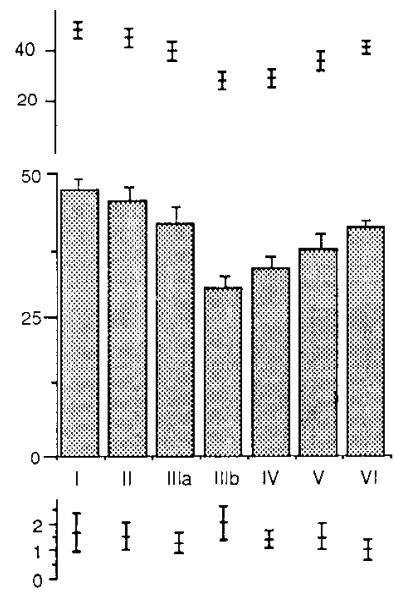

Figure 4. Histograms representing the layer-by-layer distribution of $\mathrm{D}_{1}$-specific ${ }^{3} \mathrm{H}$-SCH 22390 labeling in Walker's areas 46, 9, 12, and 25 . Error bars represent means \pm SEM. Note that layers I, II, and IIIa, as well as V and VI, contain the high concentrations of the ligand in all areas, while layers IIIb and IV are characterized by a relatively low density of labeling. The Gabriel coefficients for $B_{\max }$ values are displayed at the top of each histogram; those for $K_{d}$ values are presented at the bottom of each. In this and all subsequent histograms, $K_{d}$ or $B_{\max }$ value with overlapping confidence intervals do not differ significantly; only those with nonoverlapping intervals are statistically significant.

parison intervals are provided in the histograms of this report (Figs. 4 , $5,7,8,10,11,13$, and 14) to facilitate comparison of variation in $K_{d}$ or $B_{\max }$ within each cortical area as well as to identify the layers for which these variations are statistically significant.

Analysis of the inhibition of $\beta$-adrenergic binding of ${ }^{125} I$-iodopindolol by the $\beta-2$ specific agonist, zinterol, were performed using the Ficom program, which is a part of the PROPHET computer network. Sixteen concentrations of displacing ligand were used in this particular experiment. A typical inhibition curve is presented in Figure 2. The $F$ test, which compares the sum of the squares of the residuals, showed a statistically significant improvement of fit from a 1 -site to a 2 -site model $(p<0.05)$. FITCOMP provided percentages of low-affinity $\beta_{1}$ and highaffinity $\beta_{2}$ receptor sites and $\mathrm{IC}_{50}$ values for these sites. These percentages and the $B_{\max }$ of ${ }^{125}$ I-iodopindolol for the entire population of $\beta$ receptors were used to calculate the concentrations of $\beta_{1}$ and $\beta_{2}$ receptor sites. The $K_{i}$ 's for each receptor subtype were calculated by the method of Cheng and Prusoff (1973). The data provided by FITCOMP cannot be used to calculate standard errors of the mean or comparison intervals for $K_{i}^{\prime}$ 's.

Area 46

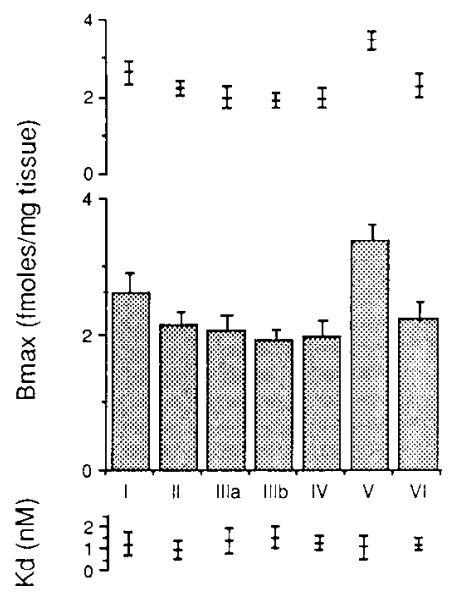

Area 12

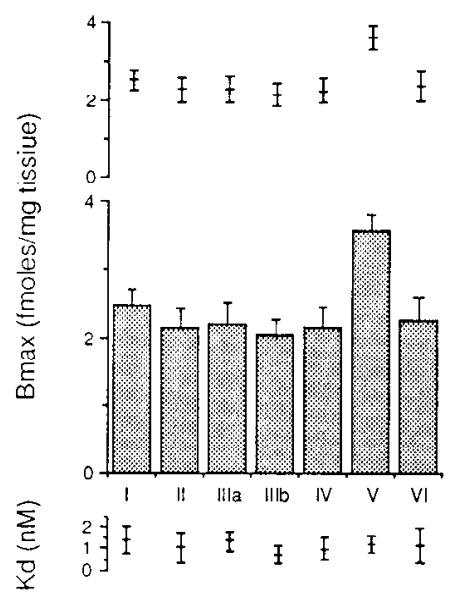

Area 9

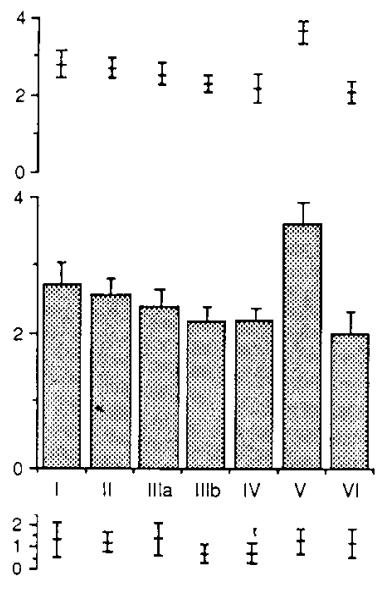

Area 25

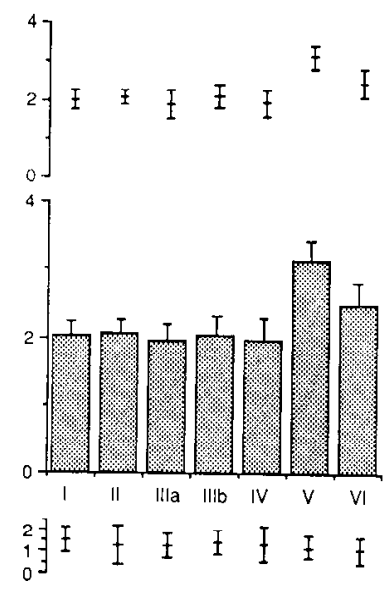

Figure 5. Histograms representing the laminar profile of $\mathrm{D}_{2}$-specific ${ }^{3} \mathrm{H}$-raclopride binding in the 4 prefrontal areas. In contrast to Figure 3 , the highest concentrations of $D_{2}$ receptors are found in layer V. Conventions as in Figure 4.

\section{Results}

Each radioligand had a characteristic laminar distribution in the prefrontal cortex with little variation over the 4 cytoarchitectonic areas examined, and the $K_{d}$ s for each ligand were statistically equivalent in all layers of all 4 areas (see Figs. 4, 5, 7, 8, $10,11,13$, and 14). Also, nonspecific binding was low and in no case exceeded $25 \%$ of total binding. The specific labeling in areas $12,46,9$, and 25 is described below both qualitatively and quantitatively.

Dopamine $D_{1}$ receptors $\left({ }^{3} \mathrm{H}-\mathrm{SCH} 23390\right)$. In the presence of mianserin, the density of ${ }^{3} \mathrm{H}-\mathrm{SCH} 23390$ binding sites in the 6 layers of the cortex ranged from $23 \mathrm{fmol} / \mathrm{mg}$ tissue to $47 \mathrm{fmol} /$ $\mathrm{mg}$ tissue. ${ }^{3} \mathrm{H}-\mathrm{SCH} 23990$-specific binding was present in every layer. However, the labeling was greatest in superficial layers I, II, and IIIa, only somewhat less dense in deep layers V and/or $\mathrm{VI}$ and least in middle layers IIIb and IV. Also, this ligand was one of the few examined that had as high or higher density in layer VI compared to layer $\mathrm{V}$. Little regional variation in binding density was observed in this pattern (Figs. $3 A, 4$ ), but area 25 contained the highest density of binding sites, particularly in the superficial layers. 


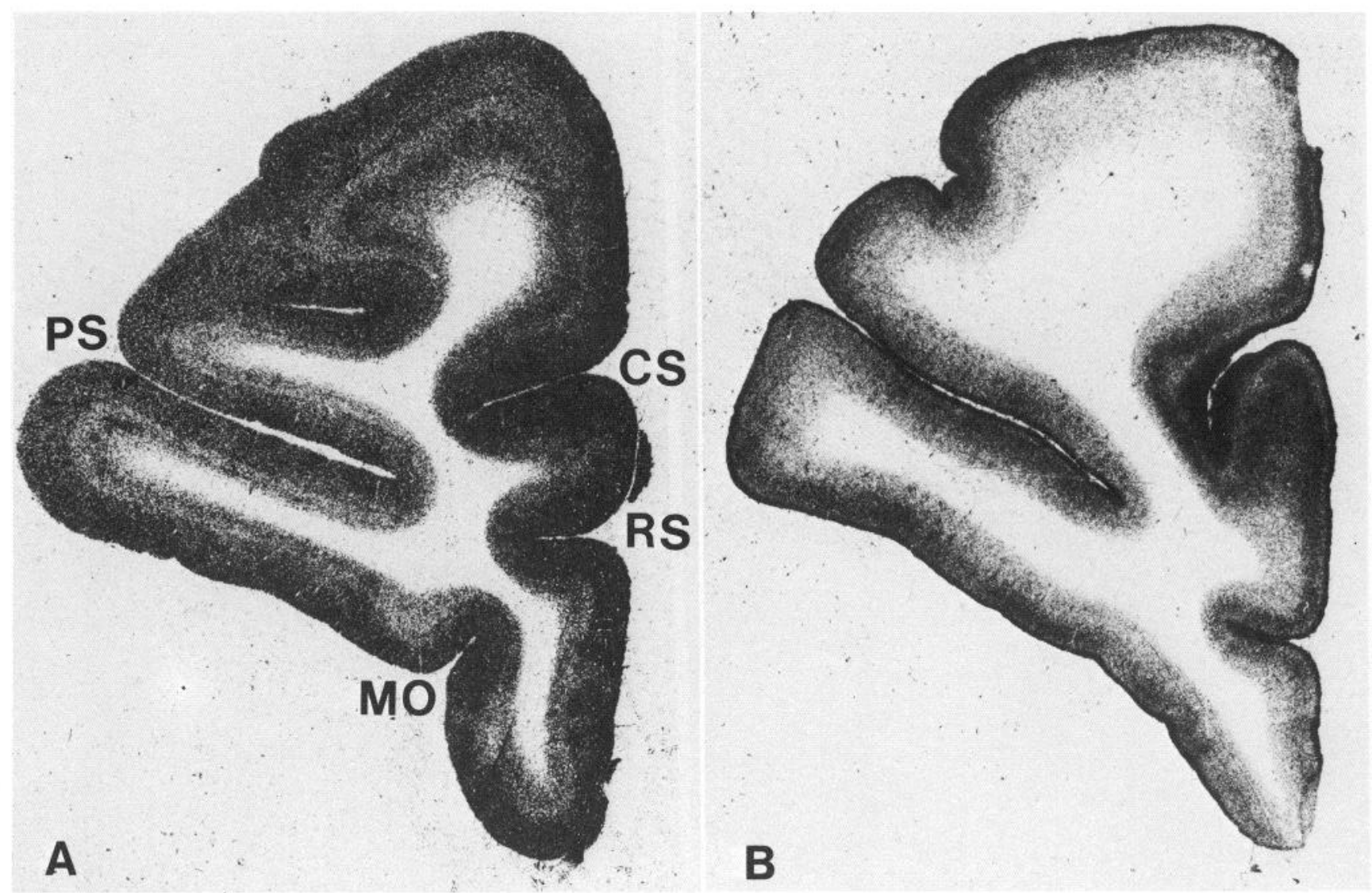

Figure 6. Autoradiographs of prefrontal sections labeled with ${ }^{3} \mathrm{H}$-prazosin $(A)$ and ${ }^{3} \mathrm{H}$-clonidine $(B)$. The complementary nature of the binding patterns in $A$ and $B$ are evident. Abbreviations as in Figure 1.

Dopamine $\mathrm{D}_{2}$ receptors $\left({ }^{3} \mathrm{H}\right.$-raclopride). The presence of $\mathrm{D}_{2}$ receptors in cerebral cortex has been questioned (for review, see DeKeyser et al., 1988a; Lidow et al., 1989d) and, indeed the $B_{\max }$ values for $\mathrm{D}_{2}$ specific binding of ${ }^{3} \mathrm{H}$-raclopride were extremely low, ranging from approximately 2 to $3.5 \mathrm{fmol} / \mathrm{mg}$ tissue across the different layers. Nevertheless, a clear and distinctive pattern of labeling resulted: $\mathrm{D}_{2}$ specific binding was consistently most concentrated in layer $\mathrm{V}$, while the binding in all other layers was lower (Figs. $3 B, 5$ ). This pattern of stratification, which was amazingly uniform in all 4 prefrontal regions, was unlike that observed with any other ligand.

$\alpha_{1}$-Adrenergic receptors $\left({ }^{3} \mathrm{H}\right.$-prazosin). The density of $\alpha_{1}$-specific binding of ${ }^{3} \mathrm{H}$-prazosin sites in the cortical layers varied from about 50 to $120 \mathrm{fmol} / \mathrm{gm}$ tissue. In all 4 prefrontal areas, $\alpha_{1}$-specific binding showed a descending pattern of concentration from layer I through layer IV and then a modest increase again in layers V and VI (areas 46 and 12) or mainly in layer $\mathrm{V}$ (areas 9 and 25) (Figs. 6A,7). This pattern was similar to that observed with the $D_{1}$-specific ligand, although the concentration of $\alpha_{1}$ binding sites in the deeper layers was lower relative to that in superficial strata. Area 25 generally contained the highest absolute binding, which was especially apparent in the supragranular layers.

$\alpha_{2}$-Adrenergic receptors $\left({ }^{3} \mathrm{H}\right.$-clonidine). The $\alpha_{2}$-specific binding of ${ }^{3} \mathrm{H}$-clonidine ranged from 22 to $62 \mathrm{fmol} / \mathrm{mg}$ tissue (Figs. $6 B, 8)$. Unlike the $\alpha_{1}$ subtype, $\alpha_{2}$ receptors generally showed a monotonic pattern of decreasing concentration from layer I through layer VI with the density in layer I being more than twice that in layer VI in all 4 prefrontal areas examined. Area 25 was the only area in which there was any deviation from this pattern. In this area, layer II binding was less than that of both adjacent layers and hence disrupted the descending concentration gradient across the layers. However, both the density and pattern of $\alpha_{2}$-specific labeling was remarkably similar among areas 9,46 , and 12 .

$\beta$-Adrenergic receptors (125 I-iodopindolol). Norepinephrine $\beta$ receptors, as measured by ${ }^{125}$ I-iodopindolol binding, had extremely low concentrations, ranging from 16 to $25 \mathrm{fmol} / \mathrm{mg}$ tissue. Although present in all layers, this labeling was denser in layers IIIa and IIIb than in deeper or more superficial layers in all areas (Figs. 9, 10). This pattern was particularly characteristic of the $\beta_{1}$ subtype which had somewhat higher concentrations than the $\beta_{2}$ subtype (Figs. 11, 12). The $\beta_{1}$ receptor also appeared to be less evenly distributed across the laminae than its $\beta_{2}$ counterpart.

5-HT, receptor $\left({ }^{3} \mathrm{H}-5-H T\right)$. The concentration of specific binding of ${ }^{3} \mathrm{H}-5-\mathrm{HT}$ in the prefrontal cortex was among the highest of all radioligands examined and had a distinctive layering pattern in which the highest density was found in the superficial layers, I, II, and IIIa, the lowest in the intermediate layers IIIb and IV and an intermediate level of binding defined the deepest layers V and VI (Figs. 13, 14). The absolute density of binding was remarkably similar from region to region, including area 25 . For example, the $B_{\max }$ values for layers I, II, and IIIa were approximately $150 \mathrm{fmol} / \mathrm{mg}$ in all 4 areas of cortex examined and half that $(75 \mathrm{fmol} / \mathrm{mg})$ in layers IIIb and IV in all 4 areas. 
Area 46

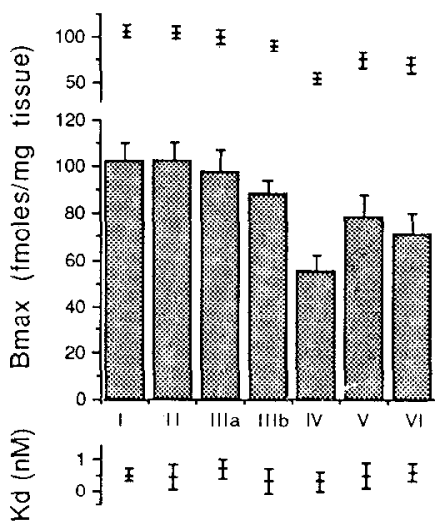

Area 12

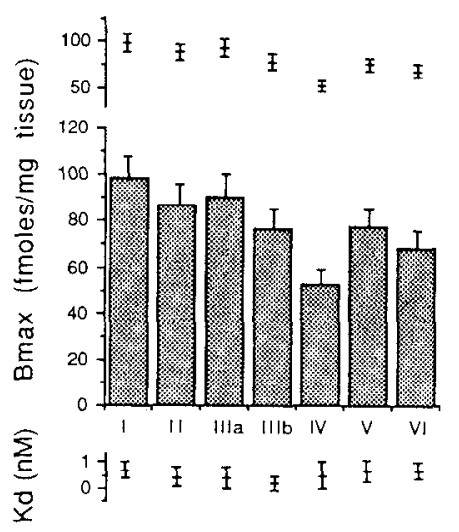

Area 9

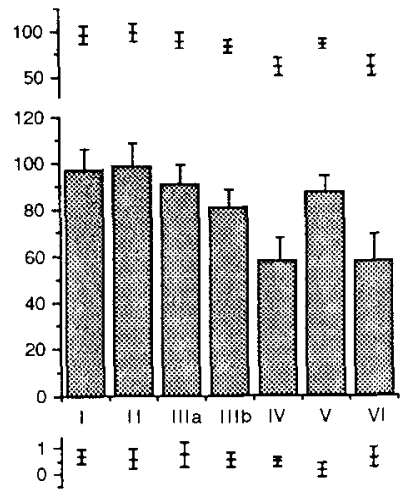

Area 25

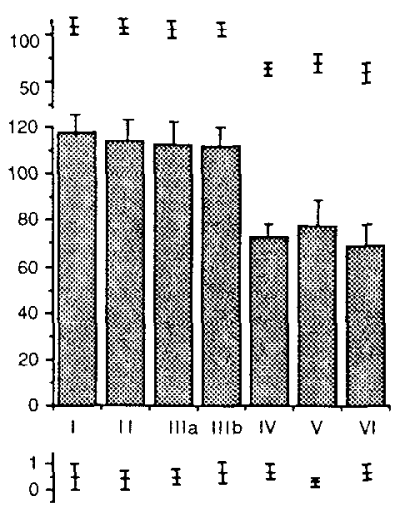

Figure 7. Histograms of layer-by-layer labeling of $\alpha_{1}$-specific ${ }^{3} \mathrm{H}$-prazosin binding. Note that the ligand is most concentrated in the superficial laminae and is least concentrated in layer IV in all 4 areas. Conventions as in Figure 4.

$5-H T_{2}$ receptors $\left({ }^{3} H\right.$-ketanserin). In the presence of prazosin (Table 1), the density of ${ }^{3} \mathrm{H}$-ketanserin binding ranged from 25 to $90 \mathrm{fmol} / \mathrm{mg}$ tissue and the laminar pattern of binding was virtually identical in all 4 prefrontal subdivisions. The highest concentrations were found in layers IIIa, IIIb, and IV, with lower values in the surrounding layers (Figs. 13, 15).

\section{Discussion}

The present analysis of 7 major monoaminergic receptor sites in the primate prefrontal cortex has revealed several findings that may have implications for understanding neurochemical interactions in normal and diseased primate cerebral cortex. First, there is considerable overlap in the location of several dopaminergic, adrenergic, and serotoninergic receptors in the prefrontal cortex. One grouping, which will be referred to as the " $S$ " group, was formed by the $\mathrm{L}_{1}, \alpha_{1}, \alpha_{2}$, and $5 \mathrm{HT}$, subtypes that were most concentrated in the superficial layers, while the $\beta_{1}, \beta_{2}, 5-\mathrm{HT}_{2}$ receptors (the "I" group) had their highest density in the intermediate layers. The $\mathrm{D}_{2}$ dopamine receptor subtype (the "D" class) alone was most concentrated in a deep layer (layer V) and evenly distributed across all others. The $D_{1}$ receptor could arguably belong to this category as $D_{1}$-specific binding was as high or higher in layer VI than in superficial strata in areas 9 and 12 .
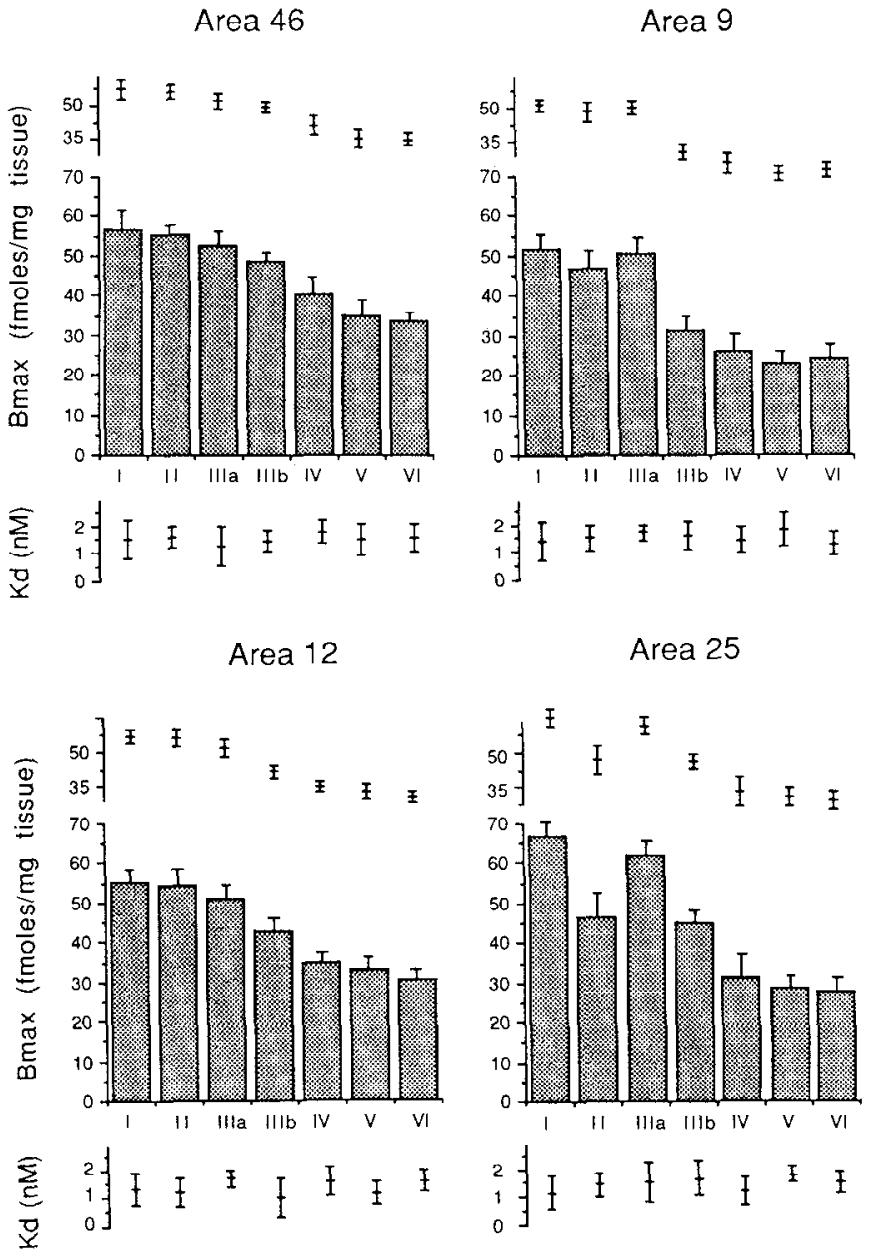

Figure 8. Histograms of $\alpha_{2}$-specific ${ }^{3} \mathrm{H}$-clonidine binding, again showing the highest concentrations to be located in the upper layers, I, II, and IIIa in all areas. Conventions as in Figure 4.

An unexpected related finding is that the peak concentrations of the diffcrent subtypes within a given neurotransmitter category were in some degree complementary. Clear differences characterized the disposition of the $\mathrm{D}_{1}$ versus $\mathrm{D}_{2}$ dopaminergic, the $\alpha$-versus $\beta$-adrenergic, and the $5-\mathrm{HT}_{1}$ versus the $5-\mathrm{HT}_{2}$ serotonergic receptors. Finally, a striking feature of the present results is the degree of similarity among different prefrontal subregions in the laminar distribution and density of each monoaminergic ligand examined. A common profile across areas was found for all monoamine receptors examined, although some receptors were more concentrated in area 25 compared with the other prefrontal regions. Each of these findings will be discussed in greater detail below.

\section{Overlapping laminar distribution of receptor subtypes}

A consistent result in the present study is the preferential localization and high concentration of the $D_{1}$ dopaminergic receptor, and $\alpha_{1}$ - and $\alpha_{2}$-adrenergic receptors, and the 5-HT sero- $^{-}$ toninergic receptor in superficial laminae I, II, and IIIa in all areas studied. Similar findings have been obtained in other areas of the cortical mantle (Rakic et al., 1988; Lidow et al., 1989a). It is tempting to speculate that the convergence of different receptors in common cortical strata reflects an association with common cortical elements such as the spine-laden, and hence 


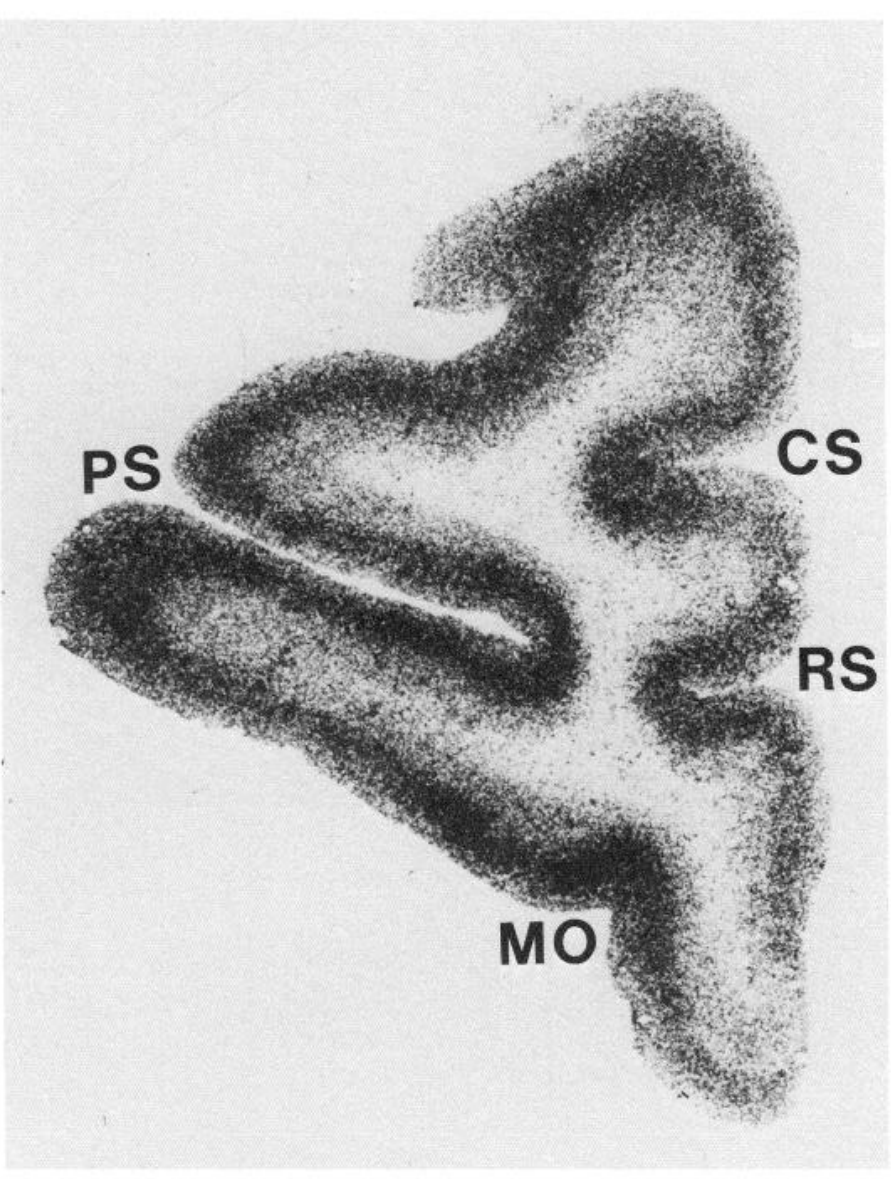

Figure 9. Autoradiograph of ${ }^{125} \mathrm{I}$-iodopindolol binding in the prefrontal cortex. Abbreviations as in Figure 1.

synapse-dense, apical dendrites of layer III and V corticocortical neurons, whose dendrites ascend vertically through the cortical layers to the upper strata. Spines are most concentrated on these apical dendrites (Globus and Scheibel, 1966, 1967; Feldman and Dowd, 1975; Parnavelas et al., 1977), and, in general, there is an exponential increase in the mean spine density with increasing distance from the cell body along the apical dendritic shaft (Valverde, 1967; see Feldman, 1984, for review). It may be relevant that the spineheads of pyramidal neurons are a prominent target of DA- or TH-positive boutons in the superficial layers of the macaque prefrontal cortex (Goldman-Rakic et al., 1989). The superficial cortical layers in prefrontal cortex are a prime location for integrative functions as they receive extensive callosal and ipsilateral corticocortical projections (Goldman-Rakic and Schwartz, 1982).

The $\beta$-adrenergic and 5- $\mathrm{HT}_{2}$ receptors were also clustered in the same layers, in this case, the intermediate thalamorecipient layers of the cortex. It is possible that these receptors may be associated predominantly with the granule cell or local circuit neurons in layer IV and/or with pyramidal neurons in layers IIIa\&b that are the main targets of mediodorsal thalamic (Giguère and Goldman-Rakic, 1988) and corticocortical (Schwartz and Goldman-Rakic, 1984) afferents in primate prefrontal cortex. In addition, the I receptors could also be associated with the smooth and/or spinous surfaces of the proximal dendrites, cell soma, and basilar dendrites of the very same pyramidal neurons that send their distal processes to the superficial layers.
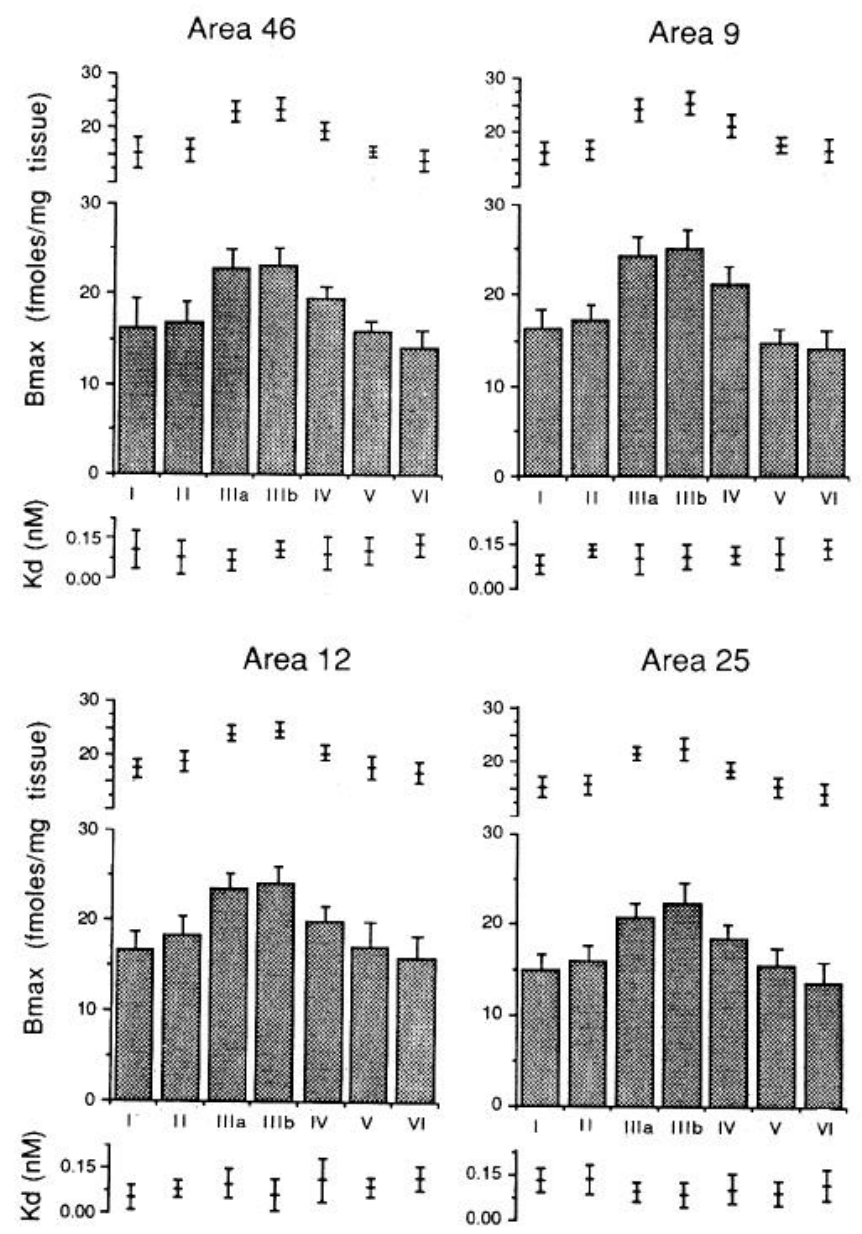

Figure 10. Histogram of $\beta$-specific ${ }^{125} \mathrm{I}$-iodopindolol binding in the various layers of the 4 prefrontal areas. Binding is most concentrated in the intermediate layers in all areas. Conventions as in Figure 4.

The unique distribution of the $\mathrm{D}_{2}$ receptor in layer $\mathrm{V}$ raises the possibility of an association with the corticostriatal and corticotectal neurons that reside in this layer. We should note, however, that because the $D_{2}$ receptor density is so low, every other receptor examined in this study has a concentration in layer V higher than that of $\mathrm{D}_{2}$, even though each is more concentrated in superficial or intermediate layers. The considerable convergence of monoaminergic receptors in the infragranular layers places them all in position to influence, to one degree or another, the output and feedback functions thought to be localized in these layers. The further dissection of the functional contribution of monoamine receptors in cortex should be aided by detailed knowledge of their precise location within the cortical mantel.

\section{Complementary distribution of receptor subtypes}

A remarkable finding in the present study is the complementary distribution of subtypes within different neurotransmitter classifications. Thus, while $D_{1}$ receptors were concentrated in the superficial and to a lesser degree, the deep strata, $D_{2}$ receptor sites were most prominent in layer V. Likewise, $\alpha$ - and $\beta$-adrenergic receptor subtypes had their highest concentration in different layers: the $\alpha$-adrenergic receptors in superficial strata (layers I, II, and IIIa); the $\beta$-adrenergic receptors in intermediate strata (IIIb and IV). Finally, the $5-\mathrm{HT}_{1}$ and $5-\mathrm{HT}_{2}$ receptors were 
Area 46

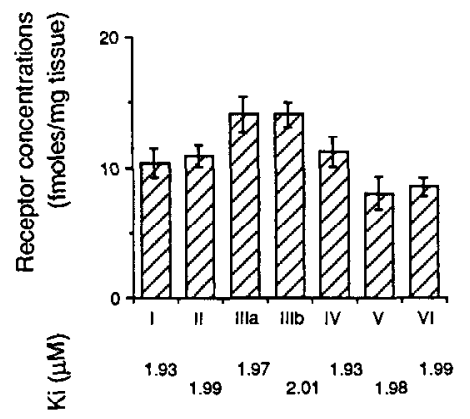

Area 12

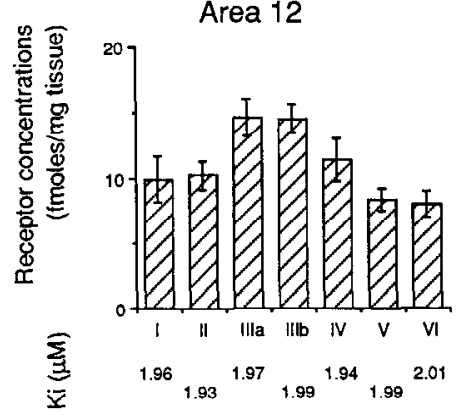

Area 9

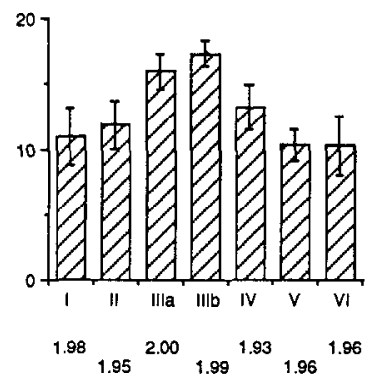

Area 25

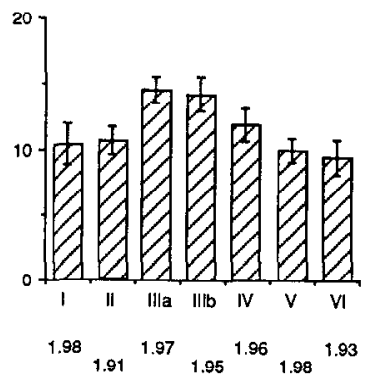

Figure 11. Histograms representing the distributions of $\beta_{1}$ receptors in prefrontal areas obtained as described in the text. Conventions as in previous histograms.

concentrated in the superficial and intermediate layers, respectively. Our quantitative analysis permitted the further characterization that for each "pair" of receptor subtypes, one subtype was always more concentrated than the other; the more concentrated was in the superficial layers and was invariably more concentrated even in the deeper layer of peak concentration of its counterpart. This cannot be due to differential subtraction since in all cases, different ligands were used to define subtype specific binding. The consistency of this pattern in all 3 neurotransmitter classes-dopaminergic, adrenergic, and serotonincrgic-is notablc. Onc clear functional implication is that the different receptor subtypes are related to different neuronal compartments, either on the same cell (e.g., soma and/or dendrites vs spines) or to different cells (e.g., projection vs. interneuron). Different target structures may, in turn, be related to dual sources of neurotransmitter innervation, as has been described for 5-HT, for example (Wilson et al., 1989). Our finding that dopamine-immunopositive boutons are widely distributed on the spines, dendritic shafts, and soma of the same pyramidal neuron (Goldman-Rakic et al., 1989) is compatible with a heterogeneous distribution of receptor subtypes at different sites along the neuron and its processes.

\section{Dopaminergic receptors in prefrontal cortex}

Among the neurotransmitter receptors examined in the present study, dopamine receptors are of special interest in relation to the sites of action of neuroleptic medications in the CNS. The recent availability of SCH23390 (Hyttel, 1982; Iorio et al., 1983) has made it possible to selectively label $D_{1}$ receptors, and using this compound in the present study we have found that $D_{1}$ receptor sites are particularly prominent in layers I, II, III (upper), V, and VI; only layers IV and lower layer III had relatively
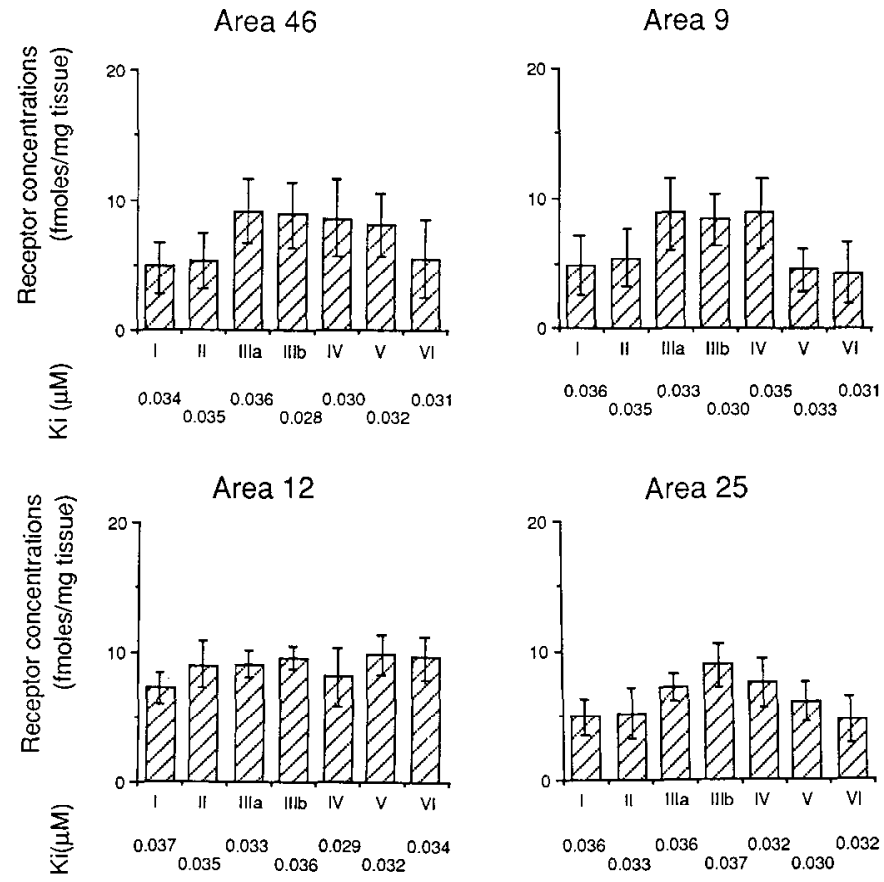

Area 25

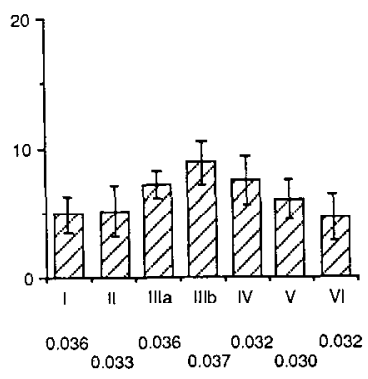

Figure 12. Histograms of $\beta_{2}$ receptors in prefrontal cortex. Conventions as in previous histograms.

few $D_{1}$ receptors. The widespread and denser distribution of $D_{1}$ receptors relative to that of the $D_{2}$ receptors in the primate prefrontal cortex is interesting in light of our recent finding that SCH23390 injected into area 46 of rhesus monkeys produced an increased latency and decreased accuracy of response in delayed-response performance, whereas $\mathrm{D}_{2}$ antagonists were without effect in this region (Sawaguchi and Goldman-Rakic, 1989). However, in the rat, blockade of the $\mathrm{D}_{2}$ receptor, but not of the $\mathrm{D}_{1}$ receptor, antagonizes dopamine's inhibitory effects on the spontaneous activity of prefrontal ncurons (Sesack and Bunncy, 1988). The role of the dopamine receptors in cortical function appears to be quite complicated and may even be different in anesthetized and awake behaving animals or on spontaneous neural activity and integrated behavior; species differences also need to be considered.

The high concentration of $\mathrm{D}_{1}$-specific ${ }^{3} \mathrm{H}-\mathrm{SCH} 23390$ binding in superficial layers of the macaque cortex found in the present study in fact differs from studies in other species. Thus, studies in rat prefrontal cortex show a high density of binding in layer V (Boyson et al., 1986; Dawson et al., 1986), layers V and VI (Richfield et al., 1989), or layers IV, V, and VI (Dawson et al., 1988). It is likely that the discrepancies in laminar profiles between the studies in rodents reflect different degrees of blocking serotoninergic binding. ${ }^{3} \mathrm{H}-\mathrm{SCH} 23390$ binds to both $5-\mathrm{HT}_{2}$ and $5-\mathrm{HT}_{1 \mathrm{C}}$ sites in addition to $\mathrm{D}_{1}$ receptors, and failure to block these additional sites significantly alters the distribution of binding by this ligand (M. S. Lidow, personal communication). Nevertheless, none of the binding patterns observed in rat matches the bilaminar distribution of ${ }^{3} \mathrm{H}-\mathrm{SCH} 23390$ binding found in the present study of monkey prefrontal cortex, even when all serotonergic sites are effectively blocked, as they were in one of these studies (Richfield et al., 1989). Thus, species 

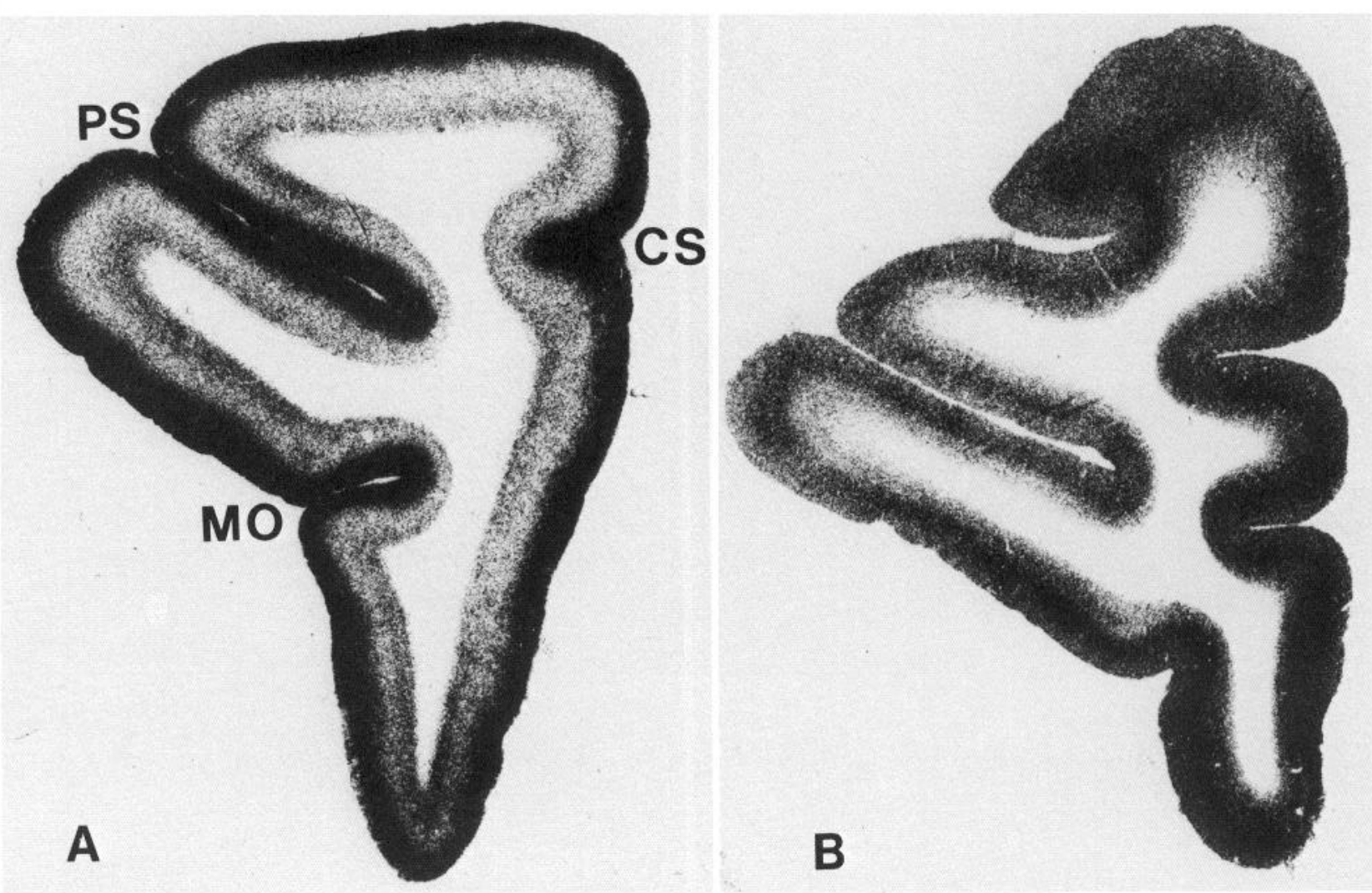

Figure 13. Autoradiographs representing ${ }^{3} \mathrm{H}-5-\mathrm{HT}(A)$ and ${ }^{3} \mathrm{H}$-ketanserin in the presence of prazosin $(B)$ binding in prefrontal areas. Note complementary pattern of binding of the 2 receptor subtypes in all prefrontal areas shown. Abbreviations as in Figure 1.

differences cannot be ruled out, particularly as a dense dopamine innervation of superficial layers in prefrontal cortex appears to be a primate specialization (Berger et al., 1988); such differences in dopamine input could explain the high concentration of $\mathrm{D}_{1}$ receptors in the superficial layers found in this study in monkey compared with comparable analyses in the rat.

${ }^{3} \mathrm{H}-\mathrm{SCH} 23390$ binding in cat prefrontal cortex is bilaminar as in the monkey, despite very high (up to $75 \%$ ) nonspecific binding (Richfield et al., 1989). However, Dawson et al. (1987) reported that the highest density of ${ }^{3} \mathrm{H}-\mathrm{SCH} 23390 \mathrm{D}_{1}$-specific binding (determined by using pifluxol as blank) in Brodmann's area 9 of human prefrontal cortex was in sublayer $\mathrm{Va}$, and no evidence of the bilaminar pattern characteristic for monkey prefrontal cortex was observed. Thus, a number of different results has been obtained in several studies of prefrontal cortex in rat, cat, monkey, and human. These differences may reflect species differences, particularly between rodent and primate, as discussed above, but a large measure of the variability across studies is likely due to the binding assays used, and specifically to the use of nonspecific ligands.

$\mathrm{D}_{2}$-binding sites are also present in all layers of the 4 prefrontal areas examined. This bears emphasis because the very existence of $\mathrm{D}_{2}$ receptors in any cortical area, including prefrontal cortex, has been questioned (see Fallon and Loughlin, 1987, for recent review). The literature ranges from reports of the complete absence of cortical $\mathrm{D}_{2}$ receptors in cortex (e.g., Altar et al., 1985; Bouthenet et al., 1985; Gehlert et al., 1985; Dubois et al., 1986; Kohler and Radesater, 1986; Charuchinda et al., 1987; DeKeyser et al., 1988) to positive findings (Carboni et al., 1985;
Liskowsi and Potter, 1985; Martres et al., 1985; Boyson et al., 1986; Camus et al., 1986; Bouthenet et al., 1985; Palacios and Pazos, 1987; Stefanini et al., 1987). In the present study of primates, we consistently found a low density of $D_{2}$ receptors in the prefrontal cortex, and similarly low concentrations were observed in our recent homogenate binding studies with the same $\mathrm{D}_{2}$-specific antagonist (Lidow et al., 1989d). These findings concur with an earlier study of rodent cortex using the $\mathrm{D}_{2}$ specific ligand 3H-iodosulpiride (Martres et al., 1985), and together with it, they provide strong evidence that the difficulty in detecting $\mathrm{D}_{2}$ receptors in the cortex is due to their low concentration combined with the use of nonspecific ligands.

The preferential localization of $\mathrm{D}_{2}$ receptors in layer $\mathrm{V}$ of primate prefrontal cortex is in agreement with a study in the rat by Martres et al. (1985). However, the relatively homogeneous cortical distribution of $\mathrm{D}_{2}$ sites reported in rat (Boyson, 1986; Richfield et al., 1989) and cat (Richfield et al., 1989) may be due to the assay conditions used. The use of ${ }^{3} \mathrm{H}$-spiperone in the presence of ketaserin (mianserin) using $(-)$ sulpiride or dopamine as blanks creates very high nonspecific binding which can reach $90 \%$ of the total binding (Richfield et al., 1989), with attendant problems in evaluating binding data. The high concentration of $\mathrm{D}_{2}$ receptors in layers I and II of human cortex found with ${ }^{3} \mathrm{H}-\mathrm{CV} 205-502$ and ${ }^{3} \mathrm{H}$-spiperone in the presence of ketanserin (Camps et al., 1989), with (+)butaclomol as a blank, also does not conform to our findings. Again, the $D_{2}$ specificity of this labeling pattern can be questioned because of the binding of both radiolabeled compounds to $\alpha$-adrenergic and 5- $\mathrm{HT}_{1 \mathrm{~A}}$ sites, in addition to the $\mathrm{D}_{2}$ sites (Lidow et al., 1989d). Also, as 
SPECIFIC BINDING OF $\left[{ }^{3} \mathrm{H}\right] 5-\mathrm{HT}$

TO 5-HT 1 SEROTONERGIC SITES

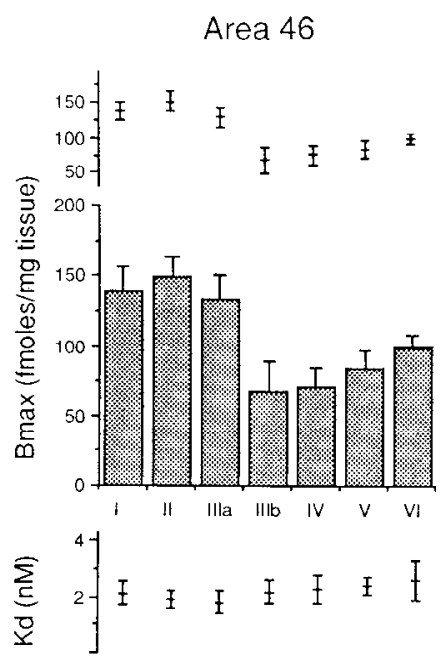

Area 12

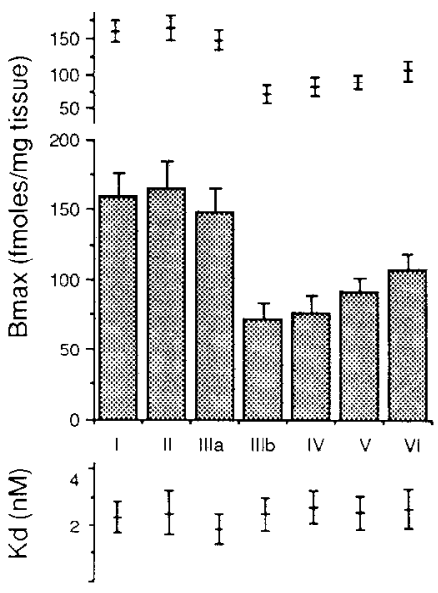

Area 9

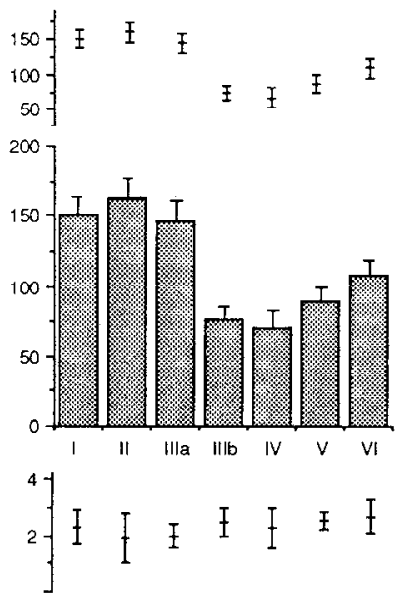

Area 25

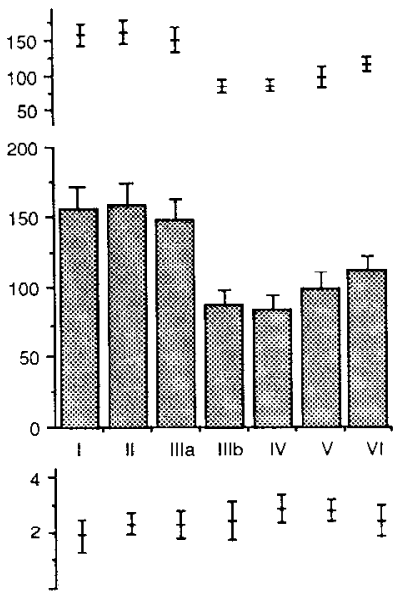

Figure 14. Histograms of 4 prefrontal areas showing the concentration of 5-HT-1 specific binding ${ }^{3} \mathrm{H}-5-\mathrm{HT}$ in the various layers. Note the high concentrations in layers I, II, and IIIa in all areas. Conventions as in Figure 4.

${ }^{3} \mathrm{H}-\mathrm{CV} 205-502$ is an agonist, the specificity of its binding is strongly dependent on assay conditions (Camus et al., 1986).

\section{Adrenergic and serotoninergic binding sites}

The distribution of adrenergic receptors also appears to exhibit species differences. For example, the highest density of $\alpha_{1}$ receptors in rat prefrontal cortex defined with ${ }^{125}$ I-HEAT (Jones et al., 1985) is found in layers III and IV, while in monkey they are highest in the superficial strata but are abundant in all layers except IV. The distributions of $\beta$-adrenergic receptors in monkey and rat prefrontal cortex found with ${ }^{125} \mathrm{I}$-iodopindolol also do not correspond. Thus, the rat has a homogenous distribution of $\beta$ sites across all cortical layers (Rainbow et al., 1984), while in monkey layers III and IV have a higher receptor density than other layers.

Our data on $5-\mathrm{HT}_{1}$-specific binding of ${ }^{3} \mathrm{H}-5-\mathrm{HT}$ in monkey are, however, in accord with findings in human prefrontal cortex (Biegon et al., 1986; Pazos et al., 1987a). In all cases, the highest binding is found in the most superficial layers. Again, however, there is a difference with rat prefrontal cortex, where ${ }^{3} \mathrm{H}-5-\mathrm{HT}$

SPECIFIC BINDING OF [3H]KETANSERIN

TO 5- $\mathrm{HT}_{2}$ SEROTONERGIC SITES

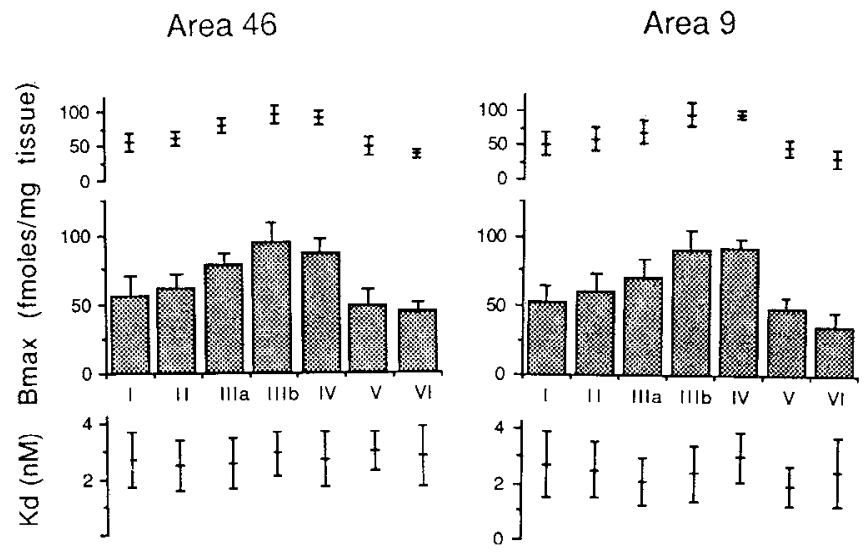

Area 12

Area 25
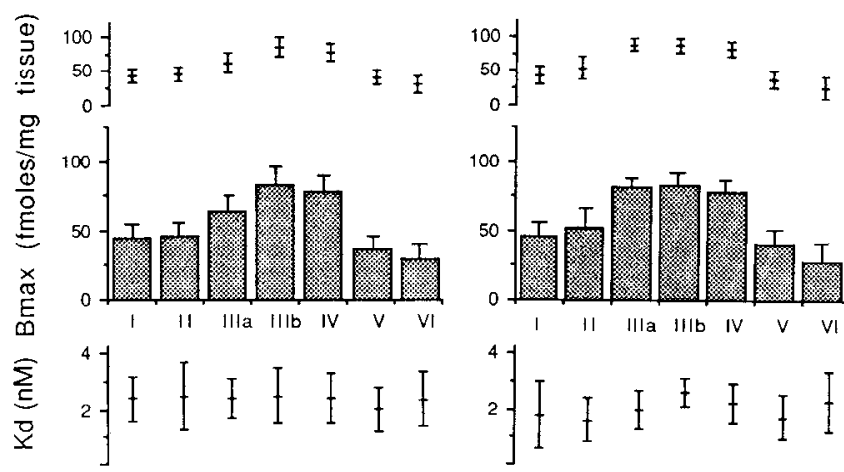

Figure 15. Laminar histograms of 5-IIT ${ }_{2}$-specific ${ }^{3} \mathrm{II}-$ ketanserin binding in the 4 prefrontal areas show the highest density present in the intermediate layers in all 4 areas. Conventions as in Figure 4.

binding is highest in layer $\mathrm{V}$ rather than in superficial layers (Pazos and Palacios, 1985), a finding reminiscent of the $D_{1}$ receptor comparison between rat and monkey described above. In contrast, the highest density $5-\mathrm{HT}_{2}$-specific binding of ${ }^{3} \mathrm{H}$ ketanserin is consistently found in the middle cortical layers in monkey, human (Pazos et al., 1987b) and rat (Pazos et al., 1985).

\section{Relationship to monoamine innervation}

The specific receptor patterns revealed in different cortical areas generally appear to correspond closely to the monoaminergic innervation of the cortex, although it is not possible from the present results to determine whether the various receptors are located presynaptically on the afferent terminals or postsynaptically on cortical neurons. TH immunohistochemistry (Lewis et al., 1988), dopamine immunohistochemistry (Goldman-Rakic et al., 1989; Williams et al., 1989), and autoradiography of ${ }^{3} \mathrm{H}$ dopamine uptake (Berger et al., 1986, 1988) all reveal a basic bilaminar pattern of fibers with a high density of fibers in superficial strata and another band in layers V/VI in several areas of prefrontal cortex. The bilamination of the dopamine innervation thus corresponds to our observations on the relatively high concentrations of $D_{1}$-binding sites in the superficial layers and $D_{1}$ and $D_{2}$ sites in the deep layers of prefrontal areas as 


\begin{tabular}{|c|c|c|c|c|c|c|c|c|}
\hline Ligand & $\begin{array}{l}\text { Site } \\
\text { labeled }\end{array}$ & $\begin{array}{l}\text { Conc. } \\
\text { (nM) }\end{array}$ & $\begin{array}{l}\text { Blank } \\
(\mu \mathrm{M})\end{array}$ & Protocol & Buffer & Time & Temp. & $\begin{array}{l}\text { Exposure } \\
\text { time }\end{array}$ \\
\hline \multirow[t]{2}{*}[{}^{3}\mathrm{H}]{$\mathrm{SCH} 23390$} & \multirow[t]{2}{*}{$\begin{array}{l}\text { dopamine } \\
\mathbf{D}_{1}\end{array}$} & \multirow[t]{2}{*}{$1-10$} & \multirow[t]{2}{*}{$\begin{array}{l}\text { SKF83566 } \\
\text { (1) }\end{array}$} & incubation & $\begin{array}{l}0.05 \mathrm{~m} \text { Tris- } \\
\mathrm{HCl}(\mathrm{pH} 7.4) \\
120 \mathrm{~mm} \mathrm{NaCl} \\
5 \mathrm{~mm} \mathrm{KCl}, 2 \mathrm{~mm}\end{array}$ & $90 \mathrm{~min}$ & $\operatorname{room} t^{\circ}$ & 3 month \\
\hline & & & & rinse & $\begin{array}{l}\mathrm{CaCl}_{2}, 1 \mathrm{~mm} \\
\mathrm{MgCl}_{2}, 1.0 \mu \mathrm{M} \\
\text { mianserin, } 0.05 \mathrm{M} \\
\text { Tris- } \mathrm{HCl}(\mathrm{pH} \\
7.4)\end{array}$ & $2 \times 10 \mathrm{~min}$ & $4^{\circ} \mathrm{C}$ & \\
\hline \multirow[t]{3}{*}[{}^{3}\mathrm{H}]{ raclopride } & \multirow[t]{3}{*}{$\begin{array}{l}\text { dopamine } \\
\mathrm{D}_{2}\end{array}$} & \multirow[t]{3}{*}{$0.3-3.0$} & \multirow[t]{3}{*}{$\begin{array}{l}\text { (+)butac- } \\
\text { lomol (1) }\end{array}$} & $\begin{array}{r}\text { preincu- } \\
\text { bation }\end{array}$ & $\begin{array}{l}50 \mathrm{~mm} \text { Tris- } \\
\mathrm{HCl}(\mathrm{pH} 7.4) \\
150 \mathrm{~mm} \mathrm{NaCl} \\
50 \mathrm{~mm} \text { Tris- } \\
\mathrm{HCl}(\mathrm{pH} 7.4)\end{array}$ & $20 \mathrm{~min}$ & room $t^{\circ}$ & 8 month \\
\hline & & & & incubation & $\begin{array}{l}150 \mathrm{~mm} \mathrm{NaCl} \\
5 \mathrm{~mm} \mathrm{KCl}_{2}, \mathrm{~mm} \\
\mathrm{CaCl}_{2}, 1 \mathrm{~mm} \\
\mathrm{MgCl}_{2}, 0.1 \%\end{array}$ & $45 \mathrm{~min}$ & room $t^{\circ}$ & \\
\hline & & & & rinse & $\begin{array}{l}\text { ascorbic acid } \\
50 \mathrm{~mm} \text { Tris- } \\
\mathrm{HCl} \text { (pH 7.4) }\end{array}$ & $6 \times 1 \mathrm{~min}$ & $4^{\circ} \mathrm{C}$ & \\
\hline \multirow[t]{3}{*}[{}^{3}\mathrm{H}]{ prazosin } & \multirow[t]{3}{*}{$\begin{array}{l}\text { norepi- } \\
\text { nephrine } \\
\alpha_{1}\end{array}$} & \multirow[t]{3}{*}{$0.2-1.0$} & \multirow[t]{3}{*}{$\begin{array}{l}\text { phenyleph- } \\
\text { rine }(100)\end{array}$} & $\begin{array}{l}\text { preincu- } \\
\text { bation }\end{array}$ & $\begin{array}{l}0.17 \mathrm{M} \text { Tris- } \\
\quad \mathrm{HCl}(\mathrm{pH} 7.1)\end{array}$ & $30 \mathrm{~min}$ & $4^{\circ} \mathrm{C}$ & 3.5 month \\
\hline & & & & incubation & same buffer & $70 \mathrm{~min}$ & $4^{\circ} \mathrm{C}$ & \\
\hline & & & & rinse & same buffer & $2 \times 5 \mathrm{~min}$ & $4^{\circ} \mathrm{C}$ & \\
\hline \multirow[t]{3}{*}[{}^{3}\mathrm{H}]{ clonidine } & \multirow[t]{3}{*}{$\begin{array}{l}\text { norepi- } \\
\text { nephrine } \\
\alpha_{2}\end{array}$} & \multirow[t]{3}{*}{$0.5-4.0$} & \multirow[t]{3}{*}{$\begin{array}{l}\text { norepineph- } \\
\text { rine }(100)\end{array}$} & preincubation & $\begin{array}{l}0.17 \mathrm{M} \text { Tris- } \\
\mathrm{HCl}(\mathrm{pH} 7.6) \\
\text { 5mM EDTA } \\
0.17 \mathrm{M} \text { Tris- }\end{array}$ & $30 \mathrm{~min}$ & $\operatorname{room} t^{\circ}$ & 3.5 month \\
\hline & & & & incubation & $\begin{array}{l}\mathrm{HCl}(\mathrm{pH} 7.6) \\
1 \mathrm{~mm} \mathrm{MnCl}_{2} \\
0.1 \% \text { ascorbic } \\
\text { acid } 0.17 \mathrm{M} \text { Tris- }\end{array}$ & $60 \mathrm{~min}$ & room $t^{\circ}$ & \\
\hline & & & & rinse & $\mathrm{HCl}(\mathrm{pH} 7.6)$ & $2 \times 5 \mathrm{~min}$ & $4^{\circ} \mathrm{C}$ & \\
\hline \multirow[t]{3}{*}{$\begin{array}{l}{\left[\begin{array}{l}125 \\
\text { pindolodo- }\end{array}\right.} \\
\text { pindolol }\end{array}$} & \multirow[t]{3}{*}{$\begin{array}{l}\text { norepi- } \\
\text { nephrine } \\
\beta\end{array}$} & \multirow[t]{3}{*}{$\begin{array}{r}0.025- \\
0.200\end{array}$} & \multirow[t]{3}{*}{$\begin{array}{l}\text { isoproter- } \\
\text { onol }(100)\end{array}$} & incubation & $\begin{array}{l}0.02 \mathrm{M} \text { Tris- } \\
\mathrm{HCl}(\mathrm{pH} \mathrm{7.4)} \\
100 \mu \mathrm{M}\end{array}$ & $70 \mathrm{~min}$ & room $t^{\circ}$ & $2 \mathrm{~d}$ \\
\hline & & & & rinse & phentolamine & & & \\
\hline & & & & & $\begin{array}{l}0.02 \mathrm{M} \text { Tris- } \\
\mathrm{HCl}(\mathrm{pH} \mathrm{7.4)}\end{array}$ & $3 \times 20 \mathrm{~min}$ & $4^{\circ} \mathrm{C}$ & \\
\hline \multirow[t]{2}{*}[{}^{3}\mathrm{H}]{$5-\mathrm{HT}$} & \multirow[t]{2}{*}{$\begin{array}{c}\text { serotonin } \\
5-\mathrm{HT}_{1}\end{array}$} & \multirow[t]{2}{*}{$2-32$} & \multirow[t]{2}{*}{$\begin{array}{l}\text { serotonin } \\
\quad(10)\end{array}$} & incubation & $\begin{array}{l}0.17 \mathrm{M} \text { Tris- } \\
\mathrm{HCl}(\mathrm{pH} 7.7) \\
0.4 \mathrm{mM} \mathrm{CaCl}_{2} \\
0.1 \% \text { ascorbic }\end{array}$ & $60 \mathrm{~min}$ & room $t^{\circ}$ & 2.5 month \\
\hline & & & & rinse & $\begin{array}{l}\text { acid, } 1 \mu \mathrm{M} \\
\text { fluoxetine } 10 \mu \mathrm{M} \\
\text { pargyline } 0.17 \mathrm{M} \\
\text { Tris- } \mathrm{HCl}(\mathrm{pH} \\
7.7)\end{array}$ & $5 \times 1.0 \mathrm{~min}$ & $4^{\circ} \mathrm{C}$ & \\
\hline \multirow[t]{3}{*}[{}^{3}\mathrm{H}]{ ketanserin } & \multirow[t]{3}{*}{$\begin{array}{c}\text { serotonin } \\
5-\mathrm{HT}_{2}\end{array}$} & \multirow[t]{3}{*}{$0.5-3.5$} & \multirow[t]{3}{*}{$\begin{array}{l}\text { methyser- } \\
\text { gide (10) }\end{array}$} & preincubation & $\begin{array}{l}0.05 \mathrm{M} \text { tris- } \mathrm{HCl}(\mathrm{pH} \\
7.7), 0.1 \mu \mathrm{M} \\
\text { prazosin }\end{array}$ & $30 \mathrm{~min}$ & room $t^{\circ}$ & 1 month \\
\hline & & & & incubation & same buffer $0.05_{M}$ & $20 \mathrm{~min}$ & room $t^{\circ}$ & \\
\hline & & & & rinse & $\begin{array}{l}\text { Tris- } \mathrm{HCl}(\mathrm{pH} \\
7.7)\end{array}$ & $5 \times 0.4 \mathrm{~min}$ & $4^{\circ} \mathrm{C}$ & \\
\hline
\end{tabular}


contrasted with the intermediate laminae. Yet the correspondence between dopamine afferents and their putative postsynaptic targets is far from precise. For example, dopamine innervation is reported to be densest in deep layer I (Berger et al., 1988; Lewis et al., 1988), whereas no marked sublamination is evident in our autoradiograms, although $\mathrm{D}_{1}$ binding tends to be slightly higher in layer I than in II and IIIb. Neither could we find a tight relationship between the ovcrall concentration of dopaminergic binding sites and the overall density of the dopamine innervation revealed by $\mathrm{TH}$ immunohistochemistry in the cytoarchitectonically defined subdivisions of the prefrontal cortex. Thus, Lewis et al. (1988) found the highest concentration of TH-immunoreactive fibers in Walker's area 9, while the lowest concentration of these fibers was found in area 46 , with intermediate concentrations in areas 12 and 25 . However, with few exceptions, the $B_{\max }$ values for $\mathrm{D}_{1}$ and $\mathrm{D}_{2}$ receptor binding in each layer were remarkably similar in all 4 areas.

The noradrenergic innervation of prefrontal cortex, like the dopaminergic innervation, is also reported to be bilaminar (Levitt et al., 1984; Lewis et al., 1988), with bands of fibers in superficial and deep strata and, according to a recent immunohistochemical analysis of dopamine- $\beta$-hydroxylase (DBH) staining, more concentrated in the deeper, especially layer $\mathrm{V}$, than superficial cortical laycrs (Lewis and Morrison, 1989). Consequently, $\alpha$-adrenergic receptors are dense in superficial layers where the norepinephrine input is weaker, although the moderate density of $\alpha_{1}$ receptors present in the deeper layers does correspond to the preferential adrenergic innervation in this layer. The discrepancy between DBH immunohistochemistry and clonidine receptor autoradiography is interesting in light of findings both in rat (U'Pritchard et al., 1979) and monkey (Arnsten and Goldman-Rakic, 1985), indicating that most of the $\alpha_{2}$ receptors in prefrontal cortex are postsynaptic.

The 5-HT input to the prefrontal cortex has variously been described as relatively uniform across layers (Lewis et al., 1986, 1988; Berger et al., 1988), somewhat more concentrated in layer IV (Lewis et al., 1985), or slightly more dense in infragranular layers (Lewis et al., 1985). The present findings on 5-HT receptors clearly demonstrate the necessity of specifying the particular receptor subtypc that is bcing "matched" or "mismatched" with afferent input. For example, the 5-HT innervation of prefrontal cortex revealed by tritiated citalopram binding is relatively uniform across layers and corresponds neither to the 5-HT, nor the $5-\mathrm{HT}_{2}$ subtypes alone but matches their combined complementary distributions (Lidow et al., 1989c). Furthermore, the 2 receptor subtypes may correlate with recent immunohistochemical evidence of dual serotonergic systems innervating the cortex - one originating in the dorsal raphe and innervating the deeper layers of the cortex and the other originating in the medium raphe and terminating in layers I and II (Wilson et al., 1989).

\section{"Prefrontal" patterns of ligand binding}

The common laminar profile of most monoamine receptors among the different prefrontal areas, although probably not strictly a function of the similar cytoarchitecture across these areas, is nevertheless in some sense a "signature" of the granular prefrontal cortex. For instance, $\beta$-adrenergic receptors are most concentrated in the superficial layers in the somatosensory areas, whereas in prefrontal areas they have a preferential distribution in the intermediate layers. Likewise, $\alpha_{2}$ receptors are densest in layer III of areas 1 and 2 and not in the superficial laminae as they are in prefrontal cortex (Lidow et al., 1989a). In addition, the muscarinic $M_{1}$ receptor is distributed differently in prefrontal cortex than in many other cortical areas (Lidow et al., 1989b). Thus, in general, the concept of a "prefrontal" archetype for rhesus monkeys seems valid and in accord with other regional differences that have previously been documented in primary and secondary visual areas (Kritzer et al., 1987; Rakic et al., 1988), as well as in primary motor and somatosensory cortices of rhesus monkeys (Lidow et al., 1989a).

\section{References}

Altar CA, Kim H, Marshall JF (1985) Computer imaging and analysis of dopamine (D-2) and serotonin (S2) binding sites in rat basal ganglia or neocortex labeled by $\left[{ }^{3} \mathrm{H}\right]$ spiroperidol. J Pharmacol Exp Ther 233: $527-538$

Aoki C, Kaufman D, Rainbow TC (1986) The ontogeny of the laminar distribution in the visual cortex of cats, normally reared and darkreared. Devel Brain Res 27:109-111.

Arnsten AFT, Goldman-Rakic PS (1985) Alpha-2 adrenergic mechanisms in prefrontal cortex associated with cognitive decline in aged nonhuman primates. Science 230:1273-1276.

Berger B, Trottier S, Gaspar P, Verney C, Alvarez C (1986) Major dopamine innervation of the cortical motor areas in the cynomolgus monkey. A radioautoradiographic study with comparative assessment of serotoninergic afferents. Neurosci Lett 72:121-127.

Berger B, Trottier S, Verney C, Gaspar P, Alvarez. C. (1988) Regional and laminar distribution of dopamine and serotonin innervation in the cynomolgus cerebral cortex. Major differences of dopamine input in the granular and agranular cortices. A radioautographic study. J Comp Neurol 273:99-119.

Bicgon A, Kargmar S, Snyder L, McEwen BS (1986) Characterization and localization of serotonin receptors in human brain postmortem. Brain Res 363:91-98.

Bischoff S, Heinrich M, Sonntag JM, Krauss J (1986) The D-1 dopamine receptor antagonist SCH23390 also interacts potently with brain serotonin (5HT-2) receptors. Eur J Pharmacol 129:367-370.

Bouthenet ML, Sales N, Schwartz JC (1985) Autoradiographic localization of $\left[{ }^{3} \mathrm{H}\right]$ apomorphine binding sites in rat brain. NaunynSchmiedberg's Arch Pharmacol 330:1-8.

Bouthenet ML, Martres MP, Sales N, Schwartz JC. (1987) A detailed mapping of dopamine D-2 receptors in rat central nervous system by autoradiography with [125]iodosulpiride. Neurosci 20:117-155.

Boyson SJ, McGonigle P, Molinoff PB (1986) Quantitative autoradiographic localization of the D-1 and D-2 subtypes of dopamine receptors in rat brain. $J$ Neurosci $6: 3177-3188$.

Camps M, Cortes R, Gueye B, Probst A, Palacios JM (1989) Dopamine receptors in human brain: autoradiographic distribution of $D-2$ sites. Neuroscience 28:275-290

Camus A, Javoy-Agid F, Dubois A, Scatton B (1986) Autoradiographic localization and quantification of dopamine D-2 receptors in normal human brain with $\left.{ }^{3} \mathrm{H}\right\rceil \mathrm{N}-\mathrm{n}$-propylnorapomorphine. Brain Res 375:135-149.

Carboni E, Memo M, Tanda GL, Carruba MO, Spasvo PF (1985) Effect of temperature and ionic environment on the specific binding of ${ }^{3} \mathrm{H}(-)$ sulpiride to membranes from different rat brain regions. Neurochem Int 7:279-284.

Charuchinda C, Supavilai P, Karobath M, Palacios JM (1987) Dopamine D-2 receptors in the rat brain: autoradiographic visualization using a high-affinity selective agonist ligand. J Neurosci 7:1352-1360.

Cheng Y, Prusoff WH (1973) Relationship between the inhibition constant $\left(\mathrm{K}_{\mathrm{i}}\right)$ and the concentration of an inhibitor that causes a $50 \%$ inhibition (IC50) of an enzimatic reaction. Biochem Pharmacol 22: 2099-2108.

Dawson TM, Gehlert DR, McCabe RT, Barnett A, Wamsley JK (1986) $\mathrm{D}-1$ dopamine receptors in the rat brain: a quantitative autoradiographic analysis. J Neurosci 6:2352-2365.

Dawson TM, McCabe RT, Stensass SS, Wamsley JK (1987) Autoradiographic evidence of $\left[{ }^{3} \mathrm{H}\right] \mathrm{SCH} 23390$ binding sites in human prefrontal cortex (Brodmann's area 9). J Neurochem 49:789-796.

Dawson TM, Barone P, Sidhu A, Wamsley JK, Chase TN (1988) The D-1 dopamine receptor in the rat brain: quantitative autoradiographic localization using an iodinated ligand. Neuroscience 26:83-100.

DeKeyser J, Claeys A, DeBacker JP, Ebinger G, Roels F, Vanquelin G 
(1988) Autoradiographic localization of D-1 and D-2 dopamine receptors in the human brain. Neurosci Lett 91:142-147.

Dubois A, Savata M, Guret O, Scatton B (1986) Autoradiographic distribution of the D-1 agonist $\left[{ }^{3} \mathrm{H}\right] \mathrm{SKF} 38393$ in the rat brain and spinal cord. Comparison with the distribution of D-2 dopamine receptors. Neuroscience 19:125-137.

Faim KE, Gessner GW, Crooke ST, Sarau HM, Weinstock J (1985) Binding of novel dopaminergic agonist radioligand $\left[{ }^{3} \mathrm{H}\right]$ fenoldopam (SKF 82526) to D-1 receptors in rat striatum. Life Sci 36:1427-1436.

Fallon JH, Loughlin SE (1987) Monoamine innervation of cerebral cortex and a theory of the role of monoamines in cerebral cortex and basal ganglia. In: Cerebral cortex, Vol 6 (Jones E, Peters A, eds), pp 41-127. New York: Plenum.

Feldman ML (1984) Morphology of the neocortical pyramidal neuron. In: Cerebral cortex, Vol 1 (Peters A, Jones EG, eds), pp. 123-200. New York: Plenum.

Feldman ML, Dowd C (1975) Loss of dendritic spines in aging cortex. Z Anat Entwicklungsgesch 148:279-301.

Fuller RW (1985) Drugs altering serotonin synthesis and metabolism. In: Neuropharmacology of serotonin (Green AR, ed), pp 1-20. New York: Oxford University Press.

Gabriel KR (1978) A simple method of multiple comparisons of means. J Am Stat Assoc 73:724-729.

Geary WA, Toga AW, Wooten GF (1985) Quantitative film autoradiography for tritium: methodological considerations. Brain Res 337: 99-108.

Gehlert DR, Wamsley JK (1985) Dopamine receptors in the rat brain. Quantitative autoradiographic localization using $\left[{ }^{3} \mathrm{H}\right]$ sulpiride. Neurochem Int 7:717-723.

Giguère M, Goldman-Rakic PS (1988) Mediodorsal nucleus: areal, laminar, and tangential distribution of afferents and efferents in the prefrontal lobe of rhesus monkeys. J Comp Neurol 277:195-213.

Globus A, Scheibel AB (1966) Loss of dendritic spines as an index of presynaptic terminal patterns. Nature 212:463-465.

Globus A, Scheibel AB (1967) Synaptic loci on visual cortical neurons of the rabbit: the specific afferent radiation. Exp Neurol 18:116-131.

Goldman-Rakic PS (1987) Circuitry of the primate prefrontal cortex and the regulation of behavior by representational knowledge. In: Handbook of physiology, the nervous system, higher functions of the brain (Plum F, ed), pp 373-417. Bethesda, MD: American Physiological Society.

Goldman-Rakic PS, Schwartz ML (1982) Interdigitation of contralateral and ipsilateral columnar projections to frontal association cortex in primates. Science 216:755-757.

Goldman-Rakic PS, Leranth C, Williams MS, Mons N, Geffard M (1989) Dopamine innervation of pyramidal neurons in primate frontal cortex. Proc Natl Acad Sci USA 86:9015-9019.

Hoyer D, Pazos A, Probst A, Palacios JM (1986) Serotonin receptors in the human brain. II. Characterization and autoradiographic localization of 5- $\mathrm{HT}_{2}$ recognition sites. Brain Res 376:97-107.

IIyttel J (1982) Citalopram: basic and clinical studies. Prog Neuropharmacol Biol Psychiatry 6:257-336.

Iorio LC, Barnett A, Leitz FH, Houser VP, Corduba CA (1983) $\mathrm{SCH} 23390$, a potential benzodiazepine antipsychotic with unique interactions on dopaminergic system. J Pharmacol Exp Ther 226: $462-468$.

Jones LS, Gauger LL, Davis JN (1985) Anatomy of brain alpha-1 adrenergic receptors: in vitro autoradiographic distribution of D-2 sites. Neuroscience 28:275-290.

Kohler C II, Radesater AC (1986) Autoradiographic visualization of dopamine D-2 receptors in the monkey brain using the selective benzamide drug $\left[{ }^{3} \mathrm{H}\right]$ raclopride. Neurosci Lett 66:85-90.

Kritzer MF, Innis RB, Goldman-Rakic PS (1987) Regional distribution of cholecystokin receptors in primate cerebral cortex determined by in vitro receptor autoradiography. J Comp Neurol 263:41 8435.

Kuhar MJ, De Souza EB, Unnerstall JR (1986) Neurotransmitter receptor mapping by autoradiography and other methods. Annu Rev Neurosci 9:27-59.

Levitt P, Rakic P, Goldman-Rakic PS (1984) Region-specific distribution of catecholamine afferents in primate cerebral cortex: a fluorescence analysis. J Comp Neurol 227:23-36.

Lewis DA, Morrison JH (1989) The noradrenergic innervation of monkey prefrontal cortex: a dopamine $\beta$-hydroxylase immunohistochemical study. J Comp Neurol 282:317-330.

Lewis DA, Campbell NJ, Foote L, Goldstein M, Morrison JH (1985)
An immunohistochemical characterization of the dopaminergic(DA), noradrenergic (NA) and serotoninergic $(5 \mathrm{HT})$ innervation of primate prefrontal and temporal cortical regions. Soc Neurosci Abstr 11:502.

Lewis DA, Campbell MJ, Foote SL, Morrison JH (1986) The monoaminergic innervation of primate neocortex. Hum Neurobiol 5:181186.

Lewis DA, Campbell MJ, Foote SL, Goldstein M, Morrison JH (1987) The distribution of tyrosine hydroxylase-immunoreactive fibers in primate neocortex is widespread but regionally specific. J Neurosci 7:279-290.

Lewis DA, Foote SL, Goldstein M, Morrison JH (1988) The dopaminergic innervation of monkey prefrontal cortex: a lyrosine hydroxylase immunohistochemical study. Brain Res 449:225-243.

Leysen JE, Niemegeers CJE, Van Neuten JM, Laduron PM (1982) ${ }^{3} \mathrm{H}-$ Ketanserin ( $R 41468$ ), a selective ${ }^{3} \mathrm{H}$ ligand for serotonin ${ }_{2}$ receptor binding sites. Mol Pharmacol 21:301-314.

Leyson JE, Eens A, Gommeren W, Van Gompel P, Waynants J, Janssen PAJ (1987) Non-serotoninergic $\left[{ }^{3} \mathrm{H}\right]$ ketanserin binding sites in striatal membranes are associated with a dopac release system on dopaminergic nerve endings. Eur J Pharmacol 134:373-375.

Lidow MS, Goldman-Rakic PS, Rakic P, Gallager DW (1988) Differential quenching and limits of resolution in autoradiograms of brain tissuc labeled with ${ }^{3} \mathrm{H}-$-, ${ }^{125} \mathrm{I}$ - and ${ }^{14} \mathrm{C}$ - compounds. Brain Res 459 : 105-119.

Lidow MS, Goldman-Rakic PS, Gallager DW, Geschwind DH, Rakic P (1989a) Distribution of major neurotransmitter receptors in the primary motor and somatosensory cortex of the rhesus monkey. Neuroscience 32:609-627.

Lidow MS, Gallager DW, Rakic P, Goldman-Rakic PS (1989b) Regional differences in the distribution of muscarinic cholinergic receptors in macaque cerebral cortex. J Comp Neurol 289:247-259.

Lidow MS, Goldman-Rakic PS, Gallager DW, Rakic P (1989c) Quantitative autoradiographic mapping of serotonin $5-\mathrm{HT}_{1}$ and $5-\mathrm{HT}_{2}$ receptors and uptake sites in the neocortex of the rhesus monkey. $\mathrm{J}$ Comp Neurol 280:27-42.

Lidow MS, Goldman-Rakic PS, Rakic P, Innis RB (1989d) Dopamine D-2 receptors in cerebral cortex and striatum of rat and monkcy: distribution and pharmacological characterization with $\left[{ }^{3} \mathrm{H}\right]$ raclopride. Proc Natl Acad Sci USA 86:6412-6416.

Liskowski DR, Potter LT (1985) D-2 dopamine receptors in the frontal cortex of rat and human. Life Sci 36:1551-1559.

Martres MP, Sales N, Bouthenet ML, Schwartz JC (1985) Localization and pharmacological characterization of D-2 dopamine receptors in rat cerebral neocortex and cerebellum using [125 I]iodosulpiride. Eur J Pharmacol 118:211-219.

Minneman KP, Hedberg A, Molinoff PB (1979) Comparison of beta adrenergic receptor subtypes in mammalian tissue. J Pharmacol Exp Ther 216:425-431.

Morrison JH, Foote II SL, O'Connor D, Bloom FE (1982) Laminar, tangential and regional organization of the noradrenergic innervation of monkey cortex: dopamine $\beta$-hydroxylase immunohistochemistry. Brain Res Bull 9:309-319.

Nicklaus KJ, McGonigle P, Molinoff PB (1988) [ $\left.{ }^{3} \mathrm{H}\right] \mathrm{SCH} 23390$ labels both dopamine-1 and 5-hydroxtrytamine-1C receptors in the choroid plexus. J Pharmacol Exp Ther 247:343-348.

Palacios JM, Pazos A (1987) Visualization of dopamine receptors: a progress review. In: Dopamine receptors (Creese I, Fraser M, eds) pp 175-197. New York: Alan Liss.

Palacios IM, Niehoff DL, Kuhar M.I (1981) Receptor autoradiography with tritium-sensitive film: potential for computerized densitometry. Neurosci Lett 25:101-105.

Parnavelas JG, Lieberman AR, Webster KE (1977) Neurons and their synaptic organization in the visual cortex, area 17 , of the rat. $J$ Anat 124:305-322.

Pazos A, Palacios JM (1985) Quantitative autoradiographic mapping of serotonin receptors in the rat brain. I. Serotonin- 1 receptors. Brain Res 346:205-230.

Pazos A, Cortes R, Palacios JM (1985) Quantitative autoradiographic mapping of serotonin receptors in the rat brain. II. Serotonin-2 receptors. Brain Res 246:231-249.

Pazos A, Probst A, Palacios JM (1987a) Serotonin receptors in the human brain-III. Autoradiographic mapping of serotonin-1 receptors. Neuroscience 21:97-122.

Pazos A, Probst A, Palacios JM (1987b) Serotonin receptors in the human brain-IV. Autoradiographic mapping of serotonin-2 receptors. Neuroscience 21:123-139. 
Rainbow TC, Biegon A (1983) Quantitative autoradiography of $\left[{ }^{3} \mathrm{H}\right]$ prazosin binding sites in rat forebrain. Neurosci Lett 40:211-226.

Rainbow TC, Parsons B, Wolfe BB (1984) Quantitative autoradiography of $\beta$-1 and $\beta$-2-adrenergic receptors in rat brain. Proc Natl Acad USA 81:1585-1589.

Rakic P, Goldman-Rakic PS, Gallager DW (1988) Quantitative autoradiography of major neurotransmitter receptors in the monkey striate and extrastriate cortex. J Neurosci 8:3670-3690.

Reader TA, Breire R, Gottberg E, Diop L, Grondin L (1988) Specific $\left[{ }^{3} \mathrm{H}\right] \mathrm{SCH} 23390$ binding to dopamine D-1 receptors in cerebral cortex and neostriatum: evidence for heterogeneities in affinity states and cortical distribution. J Neurochem 50:451-463.

Reznikoff GA, Manaker S, Rhodes CH, Winokur A, Rainbow TC (1986) Localization and quantification of beta-adrenergic receptors in human brain. Neurology 36:1067-1073.

Richfield EK, Young AB, Penney JB (1989) Comparative distributions of dopamine $D-1$ and $D-2$ receptors in the cerebral cortex of rats, cats, and monkeys. J Comp Neurol 286:409-426.

Sawaguchi T, Goldman-Rakic PS (1989) Local injections of dopamine antagonists into prefrontal cortex of monkeys induces deficits in monkey-guided saccades. Soc Neurosci Abstr 15:1156.

Schwartz ML, Goldman-Rakic PS (1984) Callosal and intrahemispheric connectivity of the prefrontal association cortex in rhesus monkey: relation between parietal and principal sulcal cortex. J Comp Neurol 226:403-420.

Schwartz ML, Zheng DS, Goldman-Rakic PS (1988) Periodicity of GABA-containing cells in primate prefrontal cortex. J Neurosci 8: 1962-1970.
Sesack SR, Bunney BS (1988) Pharmacology of dopamine-induced electrophysiological responses in the rat prefrontal cortex: D- 1 and D-2 mediated corticolimbic dopamine system. In: The mesocorticolimbic dopamine system (Kalivas PW, Nemeroff CB, eds), pp 529530. New York: NY Academy of Science.

Stefanini E, Ortu AM, Vernaleone F, Gessa GL (1987) [ $\left.{ }^{3} \mathrm{H}\right](-)$ sulpiride binding in rat striatum, cortex and anterior pituitary: an improved assay. Pharmacol Res Commun 19:777-791.

U'Pritchard DC, Bechtel WD, Rouot BM, Snyder SH (1979) Multiple apparent alpha-noradrenergic receptor binding sites in rat brain: effect of 6-hydroxydopamine. Mol Pharmacol 16:47-60.

Valverde F (1967) Apical dendritic spines of the visual cortex and light deprivation in the mouse. Exp Brain Res 3:337-352.

Walker AE (1940) A cytoarchitectural study of the prefrontal area of the macaque monkey. J Comp Neurol 73:59-86.

Williams SM, Geffard M, Goldman-Rakic PS (1989) The dopaminergic innervation of the primate frontal cortex. Soc Neurosci Abstr $15: 425$.

Wilson MA, Ricaurte GA, Molliver ME (1989) Distinct morphologic classes of serontonergic axons in primates exhibit differential vulnerability to the psychotropic drug 3,4-methylenedioxymethamphetamine. Exp Brain Res (in press).

Young WS III, Kuhar MJ (1980) Noradrenergic alpha-1 and alpha-2 receptors: light microscopic autoradiographic localization. Proc Natl Acad Sci USA 77:1696-1700. 